\title{
Individual stage selector element mutations lead to reciprocal changes in $\beta$ - vs. $\epsilon$-globin gene transcription: genetic confirmation of promoter competition during globin gene switching
}

\author{
Kevin P. Foley and James Douglas Engel \\ Department of Biochemistry, Molecular Biology, and Cell Biology, Northwestern University, Evanston, \\ Illinois 60208-3500 USA
}

\begin{abstract}
Biochemical and genetic analysis of the embryonic to adult $\beta$-like globin gene switch in chickens has led to the hypothesis that competition between the promoters of the cis-linked $\epsilon$ - and $\beta$-globin genes for interaction with a shared enhancer mediates the developmental changes in expression of $\beta$-globin protein isotypes. To test specific predictions of this promoter competition model, a sensitive RNA/polymerase chain reaction assay has been used to investigate the effects of individual $\beta$-globin promoter mutations on expression of the two linked genes in transiently transfected erythroid cells. Mutations that attenuated adult $\beta$-globin transcription resulted concomitantly in a proportional increase in expression of the embryonic $\epsilon$-globin gene. Consistent with the model, mutations disrupting the binding sites for either of two adult stage-specific transcription factors (NF-E4 and $\beta C T F$ ) indicate that these sites are essential both for induction of $\beta$-globin gene expression and for indirect suppression (through promoter competition) of $\epsilon$-globin transcription in definitive (adult) erythroid cells. These results provide direct evidence that stage-specific transcription factors affect the equilibrium existing between multiple interacting globin cis-regulatory elements. We conclude that promoter competition is an important mechanism through which developmental regulation of chicken $\beta$-globin gene switching is achieved and that such competitive interactions may prove to be generally applicable to the regulation of a variety of other temporally or spatially restricted gene expression patterns.
\end{abstract}

[Key Words: Globin gene switching; polymerase chain reaction; promoter competition; transcription factors]

Received January 22, 1992; revised version accepted February 25, 1992.

In all vertebrate species, the $\alpha$ - and $\beta$-globin loci are composed of multiple genes encoding distinct globin protein isotypes (Bunn and Forget 1986). The expression of these proteins is regulated, predominantly at the transcriptional level, during both erythroid cellular differentiation and embryonic development Bruns and Ingram 1973; Harrison 1976; Groudine et al. 1981; Evans et al. 1990 ). In chickens, the $\beta$-globin locus consists of four linked genes arranged in the order $5^{\prime}-\rho-\beta^{\mathrm{H}}-\beta-\epsilon-3^{\prime}$ (Dolan et al. 1981); transcription of each is induced following the CFU-E stage of crythroid cellular maturation (Weintraub et al. 1982). The developmental expression patterns of these genes are characterized by restriction to either (predominantly) the primitive or definitive erythroid lineages. Primitive cells are present in the blood islands by $36 \mathrm{hr}$ of development and express embryonic $\boldsymbol{\rho}^{-}$and $\boldsymbol{\epsilon}$-globin (Bruns and Ingram 1973; Brown and Ingram 1974). Beginning at approximately embryonic day 5 , erythroid cells of the definitive lineage rapidly replace these primitive cells and express hatching $\beta^{\mathrm{H}}$ - and adult $\beta$-globin (synthesis of the former is transient, whereas that of the latter continues through adult life) (Bruns and Ingram 1973; Roninson and Ingram 1983; Brown and Ingram 1974). Such developmental changes in globin expression during vertebrate embryogenesis are referred to as hemoglobin switching. Experiments in several species suggest that this process is not the result of changes in pluripotent stem cells, as proposed originally (Ingram 1972), but is programmed within a single lineage of committed erythroid progenitor cells that alter their developmental fate in response to changing signals in the extracellular environment and/or the action of an internal cellular clock (Brotherton et al. 1979; Chapman and Tobin 1979; Papayannopoulou et al. 1986; Melis et al. 1987; Stamatoyannopoulos et al. 1987 and references therein).

To delineate the molecular mechanisms regulating differential expression of the chicken $\beta$-like globin genes, recent studies have focused on defining cis-regulatory sequences and trans-acting factors required for their appropriate tissue- and developmental stage-spe- 
cific expression. A strong erythroid-specific enhancer was initially identified in the intergenic region between the $\beta$ - and $\epsilon$-globin genes; this enhancer (in collaboration with the $\beta$ - or $\epsilon$-globin promoters) is necessary and sufficient for high-level expression of both genes after transient transfection of erythroid cells /Choi and Engel 1986, 1988; Hesse et al. 1986; Nickol and Felsenfeld 1988). Achieving correct developmental regulation of each gene appears to be more complex: Although enhancer-dependent expression of the adult $\beta$-globin gene is essentially restricted to the definitive lineage, the $\epsilon$-globin gene (with the enhancer) is expressed equivalently in either primitive or definitive erythroid cells (Choi and Engel 1988; Nickol and Felsenfeld 1988). To achieve developmentally appropriate $\epsilon$-globin stage specificity, both genes plus the enhancer must be linked in cis (Choi and Engel 1988). Suppression of $\epsilon$-globin transcription in definitive erythroid cells is specifically associated with sequences between -112 and -12 bp of the adult $\beta$-globin promoter, which we have termed the stage selector element $(\mathrm{SSE})$; deletion of this region resulted in increased $\epsilon$-globin transcription in definitive cells (Choi and Engel 1988). Because duplication of the enhancer between linked $\beta$ - and $\epsilon$-globin genes permitted expression of the embryonic gene in both primitive and definitive cells, wc proposed that developmental regulation of $\epsilon$-globin transcription is a result of mutually cxclusive competition between the promoters of the two genes for interaction with the shared enhancer /Choi and Engel 1988); this is in contrast to the autonomously regulated $\beta$-globin gene, which is not dependent on competition with the embryonic gene for its stage specificity. Similar models have since been invoked to explain certain aspects of developmental regulation within the human $\beta$-like globin gene locus (see Discussion).

Biochemical analysis of proteins interacting with the chicken $\beta$-globin promoter and the $\beta / \epsilon$ enhancer has allowed the identification of a variety of DNA-binding proteins that are bclieved to function in transcriptional regulation of the locus (Emerson and Felsenfeld 1984; Emerson et al. 1985, 1987, 1989; Plumb et al. 1985, 1986; Evans et al. 1988; Lewis et al. 1988; Rupp et al. 1988; Gallarda et al. 1989a; Jackson et al. 1989; Perkins et al. 1989; Clark et al. 1990|. Of particular interest was the observation that two SSE-binding proteins appear to be expressed in definitive but not in primitive erythroid cells: $\beta C T F$ (formerly referred to as $\beta$ P-P3; Gallarda et al. $1989 \mathrm{~b}$ ), which binds to the CCAAT box; and NF-E4, which binds a purine-rich sequence located between the TATA and CCAAT boxes (Gallarda et al. 1989a). BCTFbinding activity is present in definitive cells both before (immature) and after (mature) induction of $\beta$-globin transcription, whereas NF-E4 is restricted to the mature definitive stage (Gallarda et al. 1989a). On the basis of these observations, we proposed a more detailed version of the promoter competition model /termed dueling lollipops, in reference to the two alternate DNA loops predicted to form when the $\beta / \epsilon$ enhancer interacts with either the $\beta$ or $\epsilon$-globin promoters) in which the formation of a complex between one of the two promoters and the single enhancer is dependent on the binding of stage-specific factors that alter the relative thermodynamic stability of the two potential promoter-enhancer complexes (Engel et al. 1989; Gallarda et al. 1989a). Thus, the induction of NF-E4 and $\beta C T F$ expression during definitive erythropoiesis was predicted to lead to activation of the adult $\beta$-globin gene through the binding of these two stagespecific factors to the SSE; this would then result in the indirect but coordinate suppression of $\epsilon$-globin gene transcription by shifting the proposed equilibrium to favor interaction of the enhancer with the adult promoter.

To further examine specific predictions of the promoter competition model, we have undertaken a mutational analysis of the chicken adult $\beta$-globin promoter and have determined the effects of these mutations on transcription of linked $\beta$ - and $\epsilon$-globin genes after transfection into either primitive or definitive erythroid cells. We found that mutations that attenuated expression of $\beta$-globin transcription concomitantly and proportionally increased expression of the linked $\epsilon$-globin gene, confirming a central prediction of the promoter competition model. Furthermore, these results substantiate an important role for the binding sites of two adult stage-specific transcription factors, NF-E 4 and $\beta C T F$, in the developmental regulation of these genes. These data provide compelling evidence that the trans-acting factors present in erythroid cells, by differentially affecting competitive interactions between cis-regulatory elements of the chicken $\beta$-like globin gene locus, are the principal determinants governing the developmental change in expression of $\beta$-globin isotypes during globin gene switching.

\section{Results}

Development of a quantitative RNA/PCR assay for analysis of transient transfections

We previously employed an S1 nuclease protection assay to examine expression of transiently transfected globin genes (Choi and Engel 1986, 1988; Gallarda et al. 1989a). Because of the high degree of DNA sequence identity between different members of the $\beta$-like globin gene family (Dolan et al. 1981, 1983; Dodgson et al. 1983; Roninson and Ingram 1983; Plumb et al. 1986), this assay has proved problematic to perform with adequate specificity. We therefore developed an RNA/polymerase chain reaction (PCR) assay that provides substantially improved sensitivity and specificity (Fig. 1A).

Because PCR is an exponential process, small variations in reaction conditions have a large impact on the extent of amplification (Linz 1990). Previous RNA quantitation methods utilizing PCR have therefore involved the addition of RNA or DNA templates, usually recognized by the same primers as the template to be quantified, which serve as internal controls for the reverse transcriptase and/or PCR reactions (Gilliland et al. 1990a,b; Wang and Mark 1990). Alternatively, ubiquitous endogenous mRNAs detected using a second set of primers have been employed as internal controls (Chelly et al. 
A

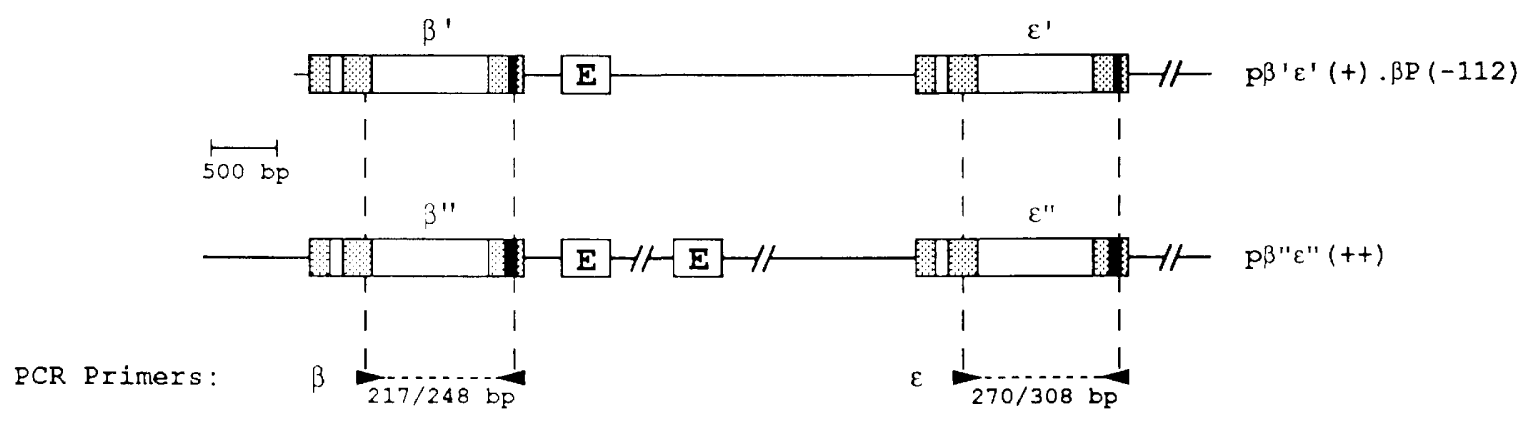

B

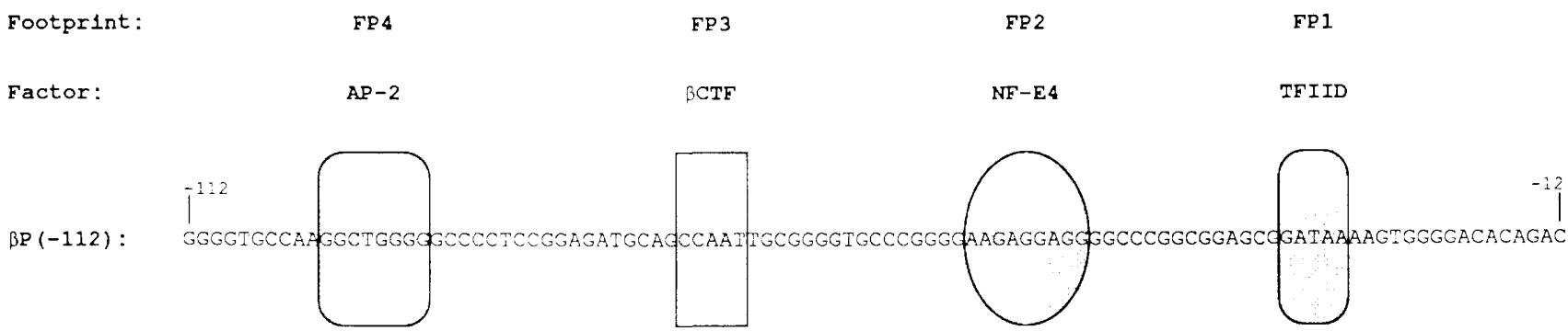

BP (-TFIID): GGGGIGCCAAGGCIGGGGGCCCCICCGGAGAIGCAGCCAAIIGCGGGG_GCCGGGGGAAGAGCAGGGGCCCGGCGAICGGGTCGCTGGTGGGGACACAGAC

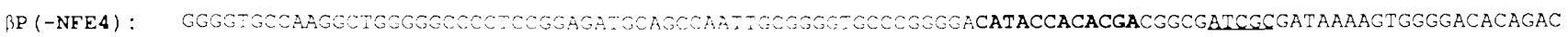

BP (NFE4/EP) : GGGG.GCCAAGGCTGGGGGCCCC.CCSGAGA-GCAGCCAAIIGCGGGGTGCGGGGGGGTGGGGAGGAGCCCGGCGATCGCGATAAAAGTGGGGACACAGAC

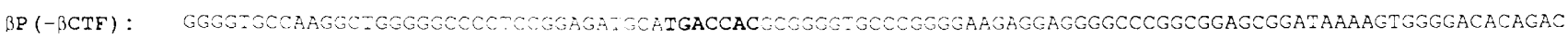

GP (-AP2): GGGGGCOATAATCTTACGCCDCACCGGAGA-GCAGCCAATTGCGGGG. GCCOGGGGAAGAGGAGGGGCCCGGCGGAGCGGATAAAAGTGGGGACACAGAC

Figure 1. Plasmids and primers used in the cotransfection RNA/PCR assay and sequences of the adult $\beta$-globin gene promoter (SSE) mutations. (A) Transcripts resulting from cotransfected $\mathrm{p} \beta^{\prime} \epsilon^{\prime}(+) \cdot \beta \mathrm{P}(-112)$ (or its derivatives containing mutations within the SSE; see below) and $\mathrm{p} \beta^{\prime \prime} \epsilon^{\prime \prime}\left(++\mid\right.$ are detected (following preparation of cDNA from total RNA of transfected cells) using either $\beta^{\prime} /{ }^{\prime \prime}-$ or $\epsilon^{\prime} /{ }^{\prime \prime}$-globin specific PCR primers (arrowheads). The primers amplify only cDNAs derived from properly spliced transcripts of the transfected, and not from the endogenous, globin genes (marked genes are indicated by rectangles labeled $\beta^{\prime}, \epsilon^{\prime}, \beta^{\prime \prime}$, and $\epsilon^{\prime \prime}$ ) due to the use of 3 ' primers specific for inserts within the third exons of the transfected genes / solid and shaded areas represent inserts and globin gene exons, respectively). Sizes of the predicted amplification products from $\beta^{\prime}(217 \mathrm{bp})$ and $\beta^{\prime \prime}(248 \mathrm{bp})$ and also $\epsilon^{\prime}(270 \mathrm{bp})$ and $\epsilon^{\prime \prime}(308$ bp) cDNAs are shown below the appropriate primer pairs (dotted lines between arrowheads), as are the positions of the identical primer binding sites in the two plasmids (vertical broken lines). The locations of the $\beta / \epsilon$ enhancers (Choi and Engel 1986; Hesse et al. 1986) (open boxes labeled $E$ ! are also indicated. $(B)$ The SSE of $\left.p \beta^{\prime} \epsilon^{\prime}|+| \cdot \beta P \mid-112\right)$ [wild-type sequence labeled $\left.\beta \mathrm{P} \mid-112\right)$ ] was replaced by modified SSEs containing the indicated mutations (bold sequences) in transcription factor-binding sites (illustrated by shaded forms superimposed on the wild-type sequence) found within the four SSE footprints (Gallarda et al. 1989a). The identities of the transcription factors that are presumed to bind to these sequences are represented above the wild-type SSE (and are used to identify each mutation) as well as the footprint (FP1-4) and nucleotide sequence numbers relative to the $\beta$-globin mRNA cap site at nucleotide +1 . Underlined sequences represent a PvuI site introduced to facilitate cloning; addition of this site had no affect on promoter activity (data not shown).

1988; Camp et al. 1991; Rupp and Weintraub 19911. Neither of these techniques, however, are suitable for analysis of transiently transfected cells because they are insensitive to variations in transfection efficiency that inevitably occur.

The assay described here overcomes these problems by measuring the expression levels of two cotransfected gene constructs (Fig. 1A): a test plasmid containing the cis-regulatory element mutation to be analyzed $\left[\mathrm{p} \beta^{\prime} \epsilon^{\prime}(+) \cdot \beta \mathrm{P}(-112)\right.$ and its derivatives], and a related internal control plasmid $\left[\mathrm{p} \beta^{\prime \prime} \epsilon^{\prime \prime}(++)\right]$. The test construct consists of an 8-kb chicken genomic DNA fragment containing both the $\beta$ - and $\epsilon$-globin genes and $\beta$-globin promoter sequences extending to $-112 \mathrm{bp}$ (Choi and Engel 1988). Both genes have been marked by the addition of 46-bp inserts at different positions within their third exons. For the mutational analyses described below, the test construct was modified in each case to differ only in the $\beta$-globin promoter region. The $\mathrm{p} \beta^{\prime \prime} \epsilon^{\prime \prime}|++|$ control construct is identical to the test con- 
struct, except that it contains larger (84-bp) inserts within the third exon of each gene (the $3^{\prime}$ end sequences in the control gene inserts are identical to those in the analogous test gene inserts). In addition, the control plasmid contains a duplication of the $\beta / \epsilon$ enhancer (thus, the connotation ++1 and $5^{\prime} \beta$-globin promoter sequences extending to $-820 \mathrm{bp}$. We refer to the marked genes in the test constructs as $\beta^{\prime}$ and $\epsilon^{\prime}$ and those in the control construct as $\beta^{\prime \prime}$ and $\epsilon^{\prime \prime}$, to distinguish them from the endogenous globin genes as well as from one another.

To detect expression of properly spliced transcripts from each gene in these constructs, two PCR primer pairs were designed to amplify regions of different lengths from either the $\beta^{\prime}$ and $\beta^{\prime \prime}$ or the $\epsilon^{\prime}$ and $\epsilon^{\prime \prime}$ genes (Fig. 1A). The 5' primer of each pair is derived from unique sequences within the second exon of the $\beta$ - or $\epsilon$-globin genes, whereas the $3^{\prime}$ primers are specific for sequences present in the third exon inserts within the test and control genes. These primer pairs therefore amplify only transcripts from the transfected genes and not the endogenous globin genes. Furthermore, unspliced mRNAs and transfected DNAs will not be detected in the assay because the primers originate in separate $\mathrm{cx}$ ons. [This approach was developed only after finding that use of $3^{\prime}$ primers specific for the 3 '-untranslated regions of each globin mRNA resulted in interference by the much more abundant endogenous globin mRNAs with exponential amplification of the control and test transcripts (data not shown).] The larger third exon inserts present in $p \beta^{\prime \prime} \epsilon^{\prime \prime}(++)$ allowed the amplification products derived from this control construct to be easily distinguished by size from those derived from $p \beta^{\prime} \epsilon^{\prime}(+) \cdot \beta P(-112)$. Additionally, duplication of the enhancer in $\mathrm{p} \beta^{\prime \prime} \epsilon^{\prime \prime}(++)$ permits expression of $\epsilon^{\prime \prime}$-globin mRNA in both primitive and definitive erythroid cells (Choi and Engel 1988).

To analyze the expression of $p \beta^{\prime} \epsilon^{\prime}(+) \cdot \beta \mathrm{P}(-112)$ and its derivatives (described below), these constructs were first cotransfected with $\mathrm{p} \beta^{\prime \prime} \epsilon^{\prime \prime}|++|$ into HD3 cells. This definitive erythroid cell line was originally generated by transformation of chicken bone marrow cells with a temperature-sensitive mutant of avian erythroblastosis virus $(\mathrm{AEV})$ and can be induced to undergo terminal erythroid maturation by shifting to the virally nonpermissive temperature (Beug et al. 1982). After differentiation induction, total RNA was isolated, reverse transcribed, amplified using the $\beta^{\prime} /{ }^{\prime \prime}$ - or $\epsilon^{\prime} /{ }^{\prime \prime}$-specific PCR primers in the presence of $\left[\alpha^{-{ }^{32 P}}\right] \mathrm{dCTP}$ and, finally, the resultant products were analyzed by denaturing polyacrylamide gel electrophoresis (see Materials and methods; Fig. 2). The sequences amplified from the test and control transcripts are virtually identical; the latter therefore provides an excellent internal control, not only for transfection efficiency but also for the reverse transcription and PCR steps of the assay. Using this method, we have compared the $\beta^{\prime} / \beta^{\prime \prime}$ and $\epsilon^{\prime} / \epsilon^{\prime \prime}$ expression ratios for a variety of different $\beta^{\prime}$-globin promoter mutations in the test construct and thereby quantitatively determined the effects of these mutations on both $\beta^{\prime}$ - and $\epsilon^{\prime}$-globin transcription (see below).
When PCR is performed for an extended number of cycles, the amplified product eventually ceases to accumulate at an exponential rate (termed the plateau effect). This is likely the result of reaction components becoming limiting as well as increasingly abundant amplification products annealing with their complementary strands rather than with the PCR primers (Innis and Gelfand 1990). As this occurs, the ratio between two different coamplification products (such as $\beta^{\prime}$ and $\left.\beta^{\prime \prime}\right)$ be comes progressively distorted and is thus no longer representative of the template ratio present in the starting sample (K.P. Foley, unpubl.). It was therefore necessary to titrate the number of amplification cycles employed for each RNA sample analyzed by RNA/PCR. This was accomplished by periodically removing aliquots from individual PCR reactions and analyzing a fraction of each to identify those in the exponential range of amplification (Fig. 2A,B). The remainder of these samples was then reanalyzed, adjusting for equal levels of the internal control (Fig. 2C,D).

To demonstrate that the assay yields a valid representation of the relative transcription levels of the test and control constructs, we examined the results obtained when varying amounts of RNA derived from a transfection of $\mathrm{p} \beta^{\prime} \epsilon^{\prime}(+) \cdot \beta P(-112)$ alone were mixed with a constant amount of RNA from a transfection of $\mathrm{p} \beta^{\prime \prime} \epsilon^{\prime \prime} \mid++1$ alone. Increasing concentrations of $p \beta^{\prime} \epsilon^{\prime}(+) \cdot \beta \mathrm{P}(-112)$ transfection RNA resulted in the expected proportional increase in both $\beta^{\prime}$ and $\epsilon^{\prime}$ products relative to those of $\beta^{\prime \prime}$ and $\epsilon^{\prime \prime}$ (Fig. 2A,B). Compared with the S1 nuclease protection assay that was employed previously for this type of analysis (Choi and Engel 1986, 1988; Gallarda et al. 1989a), we have found that the RNA/PCR assay described here not only provides improved specificity for the detection of transcription from transfected globin genes but also is far more sensitive and easier to perform. The improved sensitivity of the assay therefore makes it ideal for expression studies in cells that are difficult to isolate or in which the transcription levels of transfected constructs are very low /such as primary primitive erythrocytes, as described below). Additionally, application of this method allows analysis of cis-regulatory elements without significant disruption of a gene and without prejudice as to the location of the elements (as is done in enzymatic reporter assays currently in use).

\section{Mutational analysis of the $\beta$-globin SSE}

Because we had shown previously that the first $112 \mathrm{bp}$ of the $\beta$-globin promoter (the SSE) contains sequences necessary for suppression of $\epsilon$-globin expression in definitive erythroid cells (Choi and Engel 1988) and identified two binding activities within this region that appeared to be definitive stage specific (Gallarda et al. 1989a), we wished to investigate the roles played by individual SSEbinding proteins in mediating the developmental changes in expression of both genes; specifically, the dueling lollipop model made several predictions that allowed direct tests of its validity (Gallarda et al. 1989a). The first of these predictions was that the definitive 
Figure 2. Quantitative RNA/PCR analysis of transfected HD 3 cells. $P \beta^{\prime} \epsilon^{\prime}|+| \cdot \beta P(-1121$ and its derivatives containing modified $\beta$-globin SSEs (shown in Fig. 1B! were cotransfected with $p \beta^{\prime \prime} \epsilon^{\prime \prime} \mid++$ into HD3 cells; after differentiation induction, RNA/PCR analysis was performed on isolated total RNA using $\beta^{\prime} /{ }^{\prime \prime}-A, C$ or $\epsilon^{\prime} /{ }^{\prime \prime}$-specific $(B, D)$ primers (see Materials and methods). $\{A, B\rangle$ Control experiments were performed varying either the number of PCR cycles / to determine the exponential range of amplification for a given samplel or the ratio between starting concentrations of test $\mid \beta-$ and $\epsilon^{\prime}$-globin) and control $\left(\beta^{\prime \prime}\right.$ - and $\epsilon^{\prime \prime}$-globin! templates (to demonstrate the accuracy of the technique). RNAs from tranfections of $p \beta^{\prime} \epsilon^{\prime}\left(+\mid \cdot \beta P(-112)\right.$ and $p \beta^{\prime \prime} \epsilon^{\prime \prime}|++|$ alone are represented by $i+1$ and $\{+-1$, respectively; one unit of RNA in this experiment is equivalent to the amount recovered from $\sim 200$ transfected cells. MOCK and $(-)$ indicate mock transfection and no-template RNA/PCR negative controls, respectively. Bands resulting from amplification of the test $\left(\beta^{\prime}\right.$ and $\left.\epsilon^{\prime}\right)$, control $\left(\beta^{\prime \prime}\right.$ and $\epsilon^{\prime \prime} \mid$, and endogenous HD3 (nonglobin; ") transcripts are indicated at the sides, as are the sizes of DNA marker fragments $|M|$. (C) Analysis of $\beta^{\prime}$-globin transcription from transfected SSE mutation constructs. (D) Analysis of $\epsilon^{\prime}$-globin transcription from the identical transfected SSE mutation constructs as shown in C. The identity of each mutated promoter is as indicated in Fig. 1B, whereas $\beta P\{-820\}$ contains the entire $\beta$-globin gene promoter and $\beta P(-15)$ is deleted for the entire promoter (see Results).
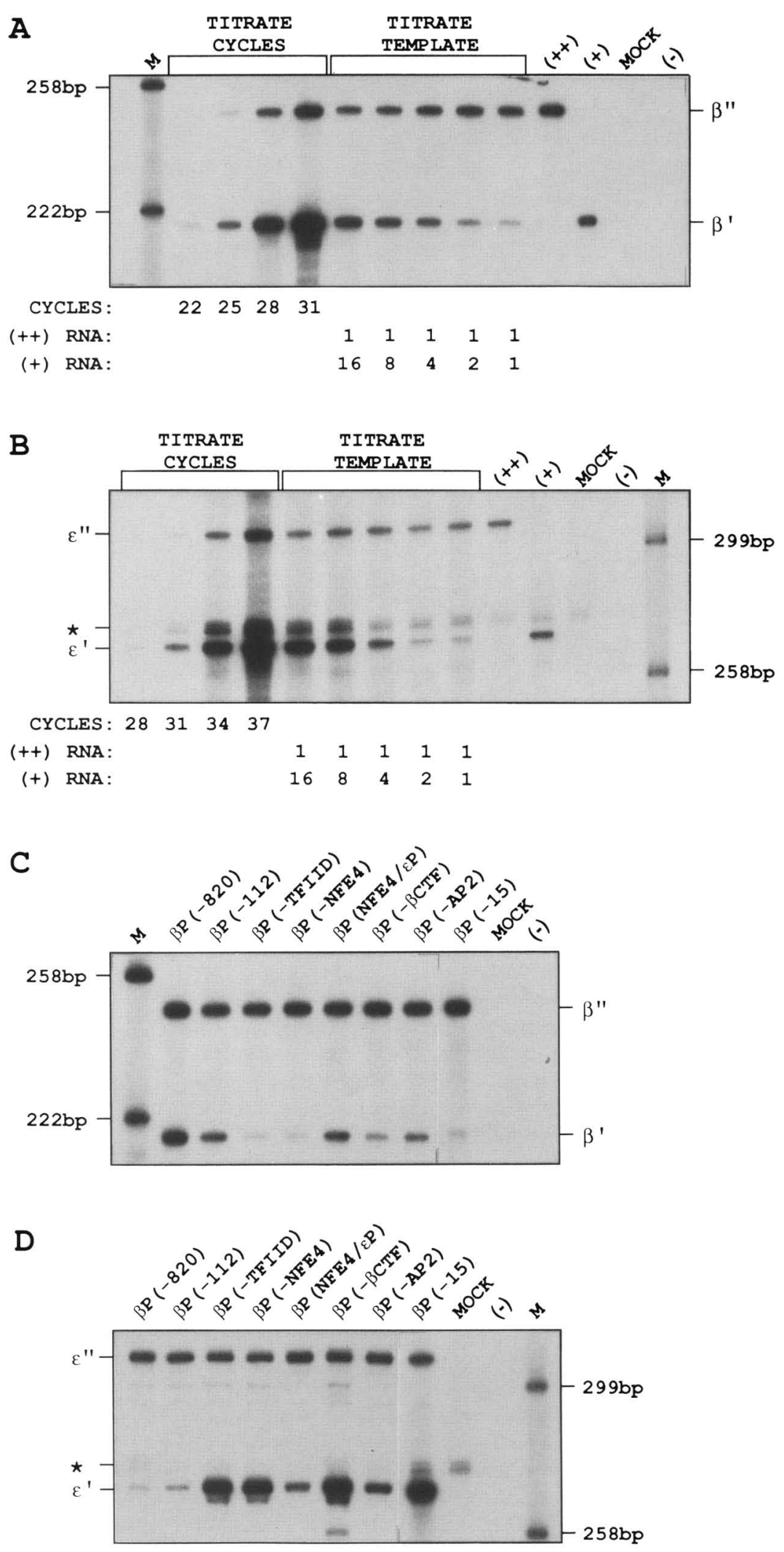

stage-specific NF-E4 and $\beta$ CTF factors, when induced during definitive erythropoiesis, stimulate $\beta$-globin tran- scription by binding to the SSE. To examine this, we mutated all four protein-binding sites (footprints) indi- 
vidually within this region (Gallarda et al. 1989a) by substitution of double-stranded oligonucleotides containing clustered mutations in each of the consensus-binding sites (Fig. 1B). The wild-type $\beta^{\prime}$-globin promoter in $p \beta^{\prime} \epsilon^{\prime}(+1 \cdot \beta P(-112)$ was replaced by each of these mutated promoters, and the constructs were then transiently cotransfected with the control plasmid $\mathrm{p}^{\prime \prime} \epsilon^{\prime \prime}|++|$ into HD3 cells and analyzed by RNA/PCR.

The results of these transfections show that mutation of each protcin-binding site within the $\beta^{\prime}$-globin promoter led to decreased transcription of the $\beta^{\prime}$-globin genc (Fig. 2C). Disruption of the TATA box (promoter footprint 1) inactivated the promoter by 10 -fold [Fig. 2C, $\beta P(-T F I I D)$, consistent with the role of the TFIID complex (which binds this site; Emerson et al. 1989) as a central component of the basal transcriptional apparatus (Sawadogo and Sentenac 1990). Mutations in both the NF-E4 (footprint 2) and $\beta C T F$ (footprint 3 ) sites also resulted in a 7 - to 10 -fold reduction in $\beta^{\prime}$-globin transcription [Fig. $2 \mathrm{C}, \beta \mathrm{P}(-\mathrm{NFE} 4)$ and $\beta \mathrm{P}(-\beta \mathrm{CTF})$; each of these three mutations decreased transcription to within approximately twofold of that achieved by deletion of the entire promoter [Fig. 2C, $\beta \mathrm{P}(-15)]$. These observations are consistent with both NF-E4 and $\beta C T F$ functioning as transcriptional activators (unlike the repressor activity suggested previously for $\beta C T F$; Emerson et al. 1989), though the proposed role for NF-E4 in displacement of a phased nucleosome from the $\beta$-globin promoter cannot be ruled out (Buckle et al. 1991). The effect of the NF-E4 mutation is more severe than we had reported previously (Gallarda et al. 1989a); this is possibly the result of our use of an earlier passage HD3 clone, which can be induced to differentiate more completely, or to the inherently more accurate internal controls used in the present assay. The most $5^{\prime}$-binding site in the SSE (footprint 4; similar to the consensus sequence for transcription factor AP-2; Roesler et al. 1988) appears to contribute less significantly to the activity of the promoter, because mutation of this site resulted in only a two- to threefold reduction in transcription [Fig. $2 \mathrm{C}, \beta \mathrm{P}(-\mathrm{AP} 2)$ ]. Similarly, deletion of $\beta^{\prime}$-globin promoter sequences between -820 and -112 bp decreased promoter activity twofold relative to the -820 bp promoter [Fig. $2 \mathrm{C}, \beta \mathrm{P}(-820)$ ], an effect generally consistent with previous reports /Choi and Engel 1986, 1988; Emerson ct al. 1989; Jackson et al. 1989). Taken together, these observations support the hypothesis that the binding of NF-E4 and $\beta$ CTF to the $\beta$-globin promoter is crucial for transcription of the gene. These data are also consistent with the postulate that both NF-E4- and $\beta$ CTF-binding activities must be present during the latter stages of definitive erythroid cellular maturation for induction of adult $\beta$-globin gene transcription, a principal prediction of the dueling lollipop model (Gallarda et al. 1989a).

\section{Mutations in the SSE increase transcription of the cis-linked $\epsilon$-globin gene}

An inherent assumption of the promoter competition model is that the equilibrium between the $\beta$ - and $\epsilon$-globin promoters, vying for interaction with the shared $\beta / \epsilon$ enhancer, is governed by the transcription factors that bind to these elements and that these factors are differentially expressed in each erythroid cell stage. Given the results showing that mutations in the SSE attenuate $\beta^{\prime}$-globin gene transcription, the model predicts further that these same mutations would cause a concomitant loss of suppression (i.e., increased transcription) of the linked $\epsilon^{\prime}$-globin gene after transfection into definitive cells. Figure 2D shows that mutations in the TATA, NF-E4, and $\beta$ CTF sites within the $\beta^{\prime}$-globin SSE resulted in a 10 - to 14 -fold increase in $\epsilon^{\prime}$-globin transcription [Fig. 2D, $\beta \mathrm{P}(-\mathrm{TFIID}), \quad \beta \mathrm{P}(-\mathrm{NFE} 4)$, $\beta P(-\beta C T F)]$, which is approximately twofold less than the level observed when the entire $\beta^{\prime}$-globin gene promoter was deleted [Fig. 2D, $\beta \mathrm{P}(-15)]$. The promoter footprint 4 (AP-2) mutation led to a fourfold increase in $\epsilon^{\prime}$ globin transcription [Fig. 2D, $\beta \mathrm{P}(-\mathrm{AP} 2)]$. Comparison of the levels of $\beta^{\prime}$ - and $\epsilon^{\prime}$-globin expression for each mutation shows that the increase in $\epsilon^{\prime}$-globin transcription was consistently proportional to the decrease in expression of the $\beta^{\prime}$-globin gene (Fig. 3), confirming a central prediction of the promoter competition model /see Discussion). Taken together, these results strongly support the hypothesis that a simple binding equilibrium with the enhancer exists between the promoters of the adult $\beta$ - and embryonic $\epsilon$-globin genes in HD3 cells and that the activation of the adult promoter/through the binding of NF-E4 and $\beta C T F$ to the SSE) alters this equilibrium toward preferential interaction of the enhancer with the SSE. Suppression of $\epsilon$-globin transcription, therefore, is the indirect effect of induction of NF-E4 and $\beta C T F$ expression in definitive cells.

\section{Analysis of $\beta$-globin SSE mutations in primary primitive erythroid cells}

Because the promoter equilibrium in definitive HD3 cells greatly favors transcription of the $\beta^{\prime}$-globin gene but does not preclude $\epsilon^{\prime}$-globin expression when the SSE is inactivated, this transformed cell line appears to parallel most closely erythroid cells in the process of switching from embryonic to adult globin synthesis (and from the primitive to definitive expression pattern; see introductory section; Pine and Tobin 1976; Chapman and Tobin 1979; Weintraub et al. 1982). Further, both the endogenous $\rho$ - and $\epsilon$-globin genes are transcribed at low levels after HD3 cells are induced to differentiate (Weintraub et al. 1982; Choi and Engel 1988). We therefore wished to examine $\beta / \epsilon$-globin promoter competition in cells uniquely committed to a single developmental stage. Expression of the mutated $\beta^{\prime}$-globin promoter plasmids was analyzed by transient transfection of primary (embryonic day 4) primitive erythrocytes isolated from developing chicken eggs; these cells express only embryonic and not adult globin protein isotypes (Bruns and Ingram 1973; Brown and Ingram 1974). We used a cationic liposome-mediated transfection protocol, rather than the ammonium chloride shock/DEAE-dextran technique described previously (Hesse et al. 1986; Lieber 


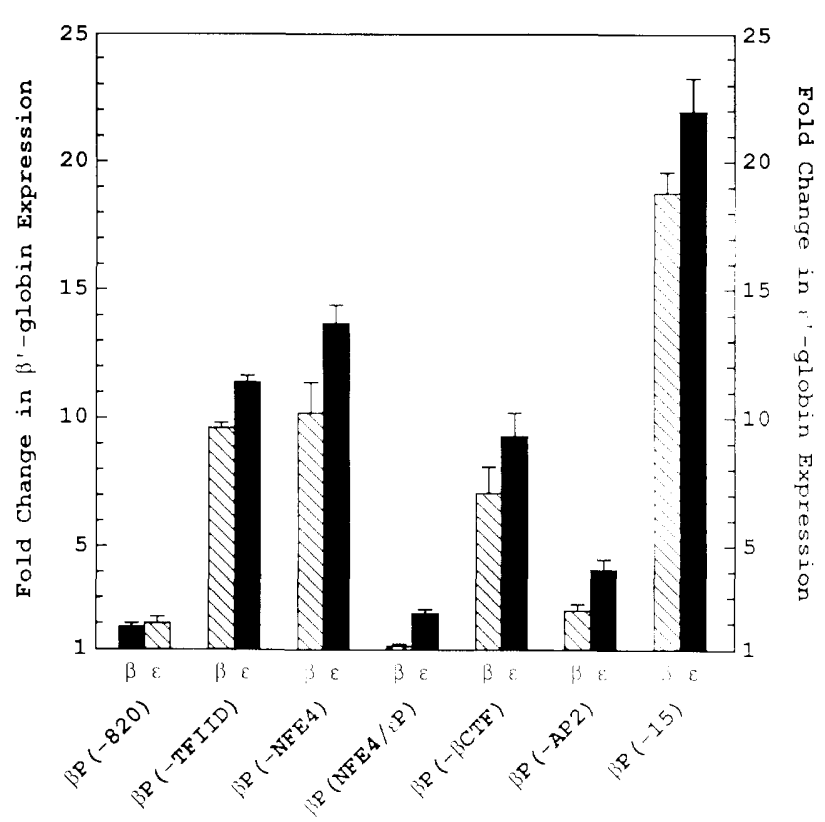

Figure 3. Stage selector element mutations result in reciprocal changes in $\beta^{\prime}$-vs. $\epsilon^{\prime}$-globin transcription. $\left.p \beta^{\prime} \epsilon^{\prime}\right\}+|\cdot \beta P|-1121$ and its derivatives containing modified $\beta^{\prime}$-globin SSEs \{identified in Fig. 1) were cotransfected with $p \beta^{\prime \prime} \epsilon^{\prime \prime}++$ into HD3 cells; following differentiation induction, RNA/PCR analysis was performed as in Fig. 2 and described in detail in Materials and methods. The results presented are the fold changes in $\beta^{\prime} /$ $\beta^{\prime \prime}|\beta|$ and $\epsilon^{\prime} / \epsilon^{\prime \prime}|\epsilon|$ ratios relative to that of wild-type $p \beta^{\prime} \epsilon^{\prime}|+| \cdot \beta P(-112)$ and represent the means $\mid \pm 1$ s.1). from three independent experiments. Increased and decreased expression are indicated by solid and hatched bars, respectively.

et al. 1987). This approach allowed the use of 50 -fold fewer cells $\left(2 \times 10^{6} /\right.$ transfection $)$ because of the combination of higher initial transfection efficiency and the increased sensitivity of the RNA/PCR assay.

When $\beta^{\prime}$-globin gene transcription was analyzed after transfection of the SSE mutation constructs (Fig. 1B) into primary primitive erythroid cells, we found that transcription of the adult gene was greatly reduced relative to that observed in HD3 cells (on the basis of the number of PCR cycles required to detect expression of $\beta^{\prime}$ - and $\beta^{\prime \prime}$ globin in a given amount of RNA; data not showni, a result consistent with previous observations (Choi and Engel 1988; Nickol and Felsenfeld 1988|. Transcription of the $\epsilon^{\prime}$-globin gene, however, was detected easily (Fig. 4). Interestingly, mutations in the $\beta^{\prime}$-globin SSE still affected transcription of the embryonic gene in these cells: Each mutation that was shown to reduce $\beta^{\prime}$-globin $\mathrm{ex}$ pression in the $\mathrm{HD} 3$ cell line consistently resulted in a $30-50 \%$ increase in $\epsilon^{\prime}$-globin transcription relative to the -112 bp promoter (Fig. 4). These observations provide empirical support for two important conclusions: First, the equilibrium between the $\epsilon$ - and $\beta$-globin promoters is active in primitive cells but strongly favors interaction of the embryonic e-globin promoter with the enhancer; and second, these results are consistent with the proposal (see introductory section) that switching from the primitive to definitive lineages is a process in which primitive erythroid cells gradually acquire progressively greater definitive expression characteristics.

\section{A composite $\beta / \epsilon$-globin promoter with altered stage specificity}

Comparison of the proximal promoter sequences of the $\beta$ - and $\epsilon$-globin genes shows that the footprinted regions of the SSE are highly conserved between these two elements (Engel et al. 1989; Gallarda et al. 1989a). The exception to this uniformity is the binding site for NF-E4 within the SSE; this purine-rich region contains 4 nucleotide changes when compared to the $\epsilon$-globin promoter (Engel et al. 1989). These sequence differences suggest that a factor other than NF-E4 might interact with this related site and could thereby contribute to developmentally modulated competition between the two promoters. To investigate this possibility, $p \beta^{\prime} \epsilon^{\prime}(+) \cdot \beta P(-112)$ was altered to include the 4 nucleotide changes found in

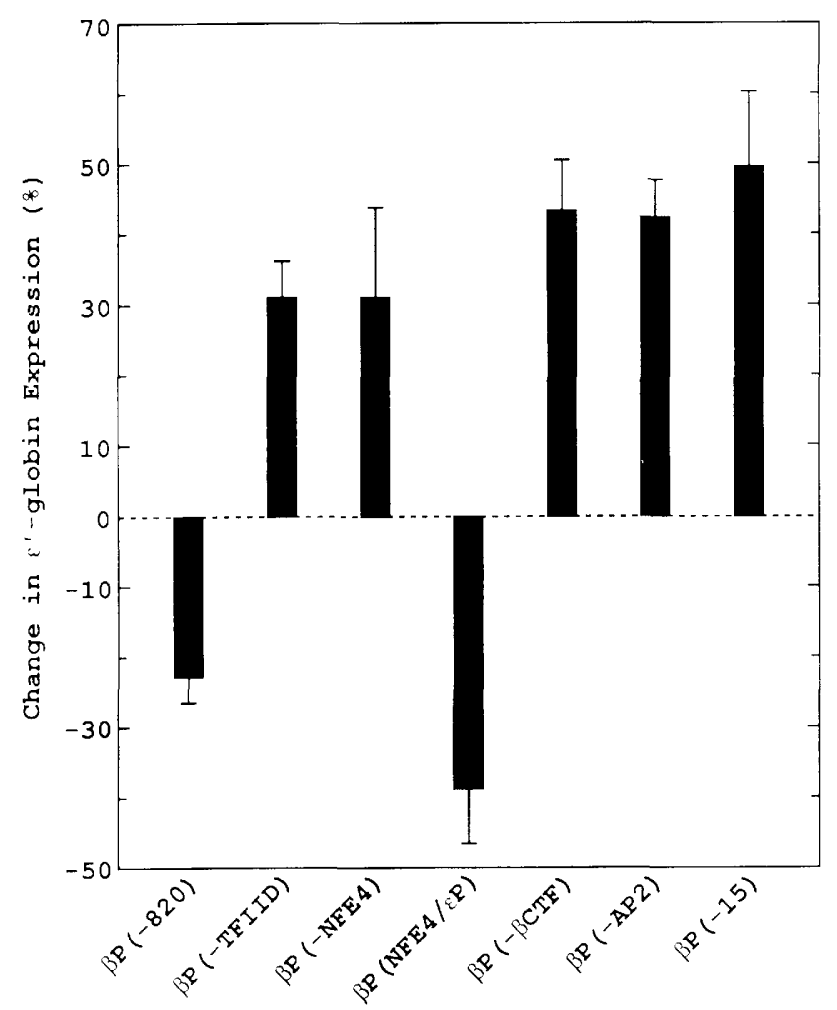

Figure 4. Quantitative RNA/PCR analysis of transfected primary primitive erythrocytes. $\mathrm{p} \beta^{\prime} \epsilon^{\prime}|+| \cdot \beta \mathrm{P}(-112)$ and its derivatives containing modified $\beta^{\prime}$-globin SSEs (identified in Fig. 1) were cotransfected with $\mathrm{p} \beta^{\prime \prime} \epsilon^{\prime \prime}(++)$ into embryonic day 4 chicken erythrocytes; after $48 \mathrm{hr}$, quantitative RNA/PCR analysis was performed on isolated total RNA using $\epsilon^{\prime} /$ ' $^{\prime}$-specific primers (see Materials and methods). The results presented are the percent changes in $\epsilon^{\prime} / \epsilon^{\prime \prime}$ ratios relative to that of $p \beta^{\prime} \epsilon^{\prime}|+| \cdot \beta P(-112)$ (displayed in this format because the high nonspecific background in primitive cell transfections make these relatively small changes in expression difficult to visually interpret) and represent the means ( \pm 1 S.D.) of three independent experiments. 
the analogous $\epsilon$-globin promoter site [Fig. 1B, $\beta \mathrm{P} / \mathrm{NFE} 4 /$ $\epsilon \mathrm{P} \mid$, with the expectation that introduction of this $\mathrm{mu}-$ tation into the SSE might alter the stage specificity of $\beta^{\prime}$-globin gene transcription. This mutation resulted in a modest $(10 \%)$ reduction of $\beta^{\prime}$-globin expression in differentiated HD3 cells [Fig. 2C, $\beta \mathrm{P}(\mathrm{NFE} 4 / \epsilon \mathrm{P})]$ and, correspondingly, a twofold increase in $\epsilon^{\prime}$-globin transcription $[$ Fig. $2 \mathrm{D}, \beta \mathrm{P}(\mathrm{NFE} 4 / \epsilon \mathrm{P})]$. Conversely, in primitive cells this mutation had the opposite effect, resulting in a $40 \%$ reduction in $\epsilon^{\prime}$-globin accumulation [Fig. 3, $\beta \mathrm{P}(\mathrm{NFE} 4 /$ $\left.\epsilon \mathrm{P}\right|_{\text {; }}$ the low level of $\beta^{\prime}$-globin gene transcription in primitive erythroid cells precluded accurate quantitation because of the high nonspecific background level (data not shown)]. These observations are most consistent with a model in which a factor, present in both primitive and $\mathrm{HD} 3$ cells and therefore distinct from NF-E4, binds to the $\epsilon$-globin promoter in a similar position to the NF-E4binding site within the SSE. In HD3 cells, the binding of this factor can apparently functionally substitute for NFE4 binding; with each promoter now binding a similar complement of proteins, the promoter equilibrium is altered toward increased $\epsilon^{\prime}$-globin transcription. It appears, however, that the $\beta^{\prime}$-globin promoter containing this mutation is still quite active in definitive erythroid cells; we assume that this may be attributable to the binding of different CCAAT-box factors to each promoter las suggested by DNase I footprinting data; Gallarda et al. 1989a) or to other regulatory elements outside of the proximal promoters. In primitive cells, the observed decrease in $\epsilon^{\prime}$-globin expression is the expected result fon the basis of the promoter competition model; Engel ct al. 1989; Gallarda et al. 1989a) of activation of the $\beta^{\prime}$-globin gene through the binding of such an $\epsilon$-globin promoter factor to the altered SSE.

\section{Discussion}

Here, we describe the most recent aspects in the evolution of a regulatory model for the chicken embryonic to adult $\beta$-like globin gene switch in which the expression of definitive stage-specific transcription factors alters the competition between the $\epsilon$ - and $\beta$-globin promoters for interaction with their shared enhancer/Choi and Engel 1988; Engel et al. 1989; Gallarda et al. 1989a). These experiments demonstrate that several key predictions of the promoter competition model are correct, and we draw from these results two principal conclusions: first, that definitive stage-specific induction of $\beta$-globin transcription is dependent on the binding sites of both NF-E4 and $\beta$ CTF within the SSE; and sccond, that SSE activation is required for suppression of $\epsilon$-globin transcription in definitive cells. In the first instance, NF-E4 and $\beta C T F$ appear to act as transcriptional activators directly on the $\beta$-globin promoter; in the second, however, they likely function indirectly by mediating preferential association between the enhancer and the adult promoter, thereby preventing enhancer-dependent $\epsilon$-globin gene transcription. These results strongly support the existence of a competitive promoter-enhancer equilibrium and demonstrate directly that this competition is dependent on the utilization of specific transcription factor-binding sites.

\section{Autonomous regulation of $\beta$-globin transcription is} mediated NF-E4 and $\beta C T F$

Control of globin gene expression can be divided into two distinct but overlapping processes: developmental regulation in primitive versus definitive erythroid cells; and induction during late erythroid maturation in each of these lineages. For the chicken adult $\beta$-globin gene, each of these processes is controlled through the SSE and $\beta / \epsilon$ enhancer (Choi and Engel 1986, 1988). Biochemical analysis has identified a number of developmental and maturation stage-specific transcription factors (as well as ubiquitous factors) that interact with these elements (Plumb et al. 1986; Emerson et al. 1987, 1989; Lewis et al. 1988; Gallarda et al. 1989a; Jackson et al. 1989; Yamamoto et al. 1990). Of particular interest to this study, the SSE is bound by $\beta$ CTF in immature and mature definitive cells, whereas NF-E4 binds only in the latter cell type; neither of these factors appears to be present in primitive erythroid cells (Gallarda et al. 1989a). These results suggest a role for NF-E4 and $\beta$ CTF in activation of $\beta$-globin transcription during definitive erythroid mat uration. By analyzing the expression of $\beta^{\prime}$-globin genes mutated in single binding sites within the SSE, we have found that both the NF-E4 and $\beta$ CTF sites are essential for $\beta^{\prime}$-globin transcription in definitive cells (Figs. 2C and 31 . Because other stage-specific factors that bind to the $\beta$-globin promoter and enhancer contribute only moderately to transcriptional activation of the adult gene (Emerson et al. 1987, 1989; Reitman and Felsenfeld 1988; Jackson et al. 1989/ and because the SSE and enhancer are sufficient for correct developmental regulation of $\beta$-globin transcription (Choi and Engel 1988), it can be argued that NF-E4 and $\beta C T F$ are the primary determinants of $\beta$-globin gene stage specificity. Clearly, however, other transcription factors are also necessary to achieve fully regulated expression. The activities of NFE4 and $\beta C T F$ are likely complemented by that of the PAL factor, which binds $5^{\prime}$ to the SSE and appears to regulate repression of $\beta$-globin transcription in terminally mature erythrocytes (Emerson et al. 1989; Jackson et al. 1989). Members of the GATA transcription factor family (which are capable of binding to the enhancer and are differentially expressed during erythropoiesis) have also been hypothesized to play a role in the induction and stage specificity of $\beta$-globin expression /Whitelaw et al. 1990; Yamamoto et al. 1990; Engel et al. 1991), a possibility currently under active investigation. Final proof that the activities of NF-E4 and $\beta C T F$ are causally related to the stage-specific transcription of the adult $\beta$-globin gene awaits the cloning and functional analysis of these proteins.

Developmental changes in the $\beta / \epsilon$ dueling lollipop equilibrium are regulated by NF-E4 and $\beta C T F$

On the basis of the adult stage-specific binding of NF-E4 
and $\beta C T F$ to the SSE, we proposed that these factors contribute to the formation of a thermodynamically stable complex between the SSE and $\beta / \epsilon$ enhancer, thereby resulting in a lack of enhancer activity available to the $\epsilon$-globin promoter in definitive cells /Gallarda et al. 1989a). The requirement of NF-E4- and $\beta C T F$-binding sites for $\beta^{\prime}$-globin transcription suggests that these two transcription factors act by potentiating protein-protein interactions between factors binding to the SSE and to the enhancer [this complements the previously ident1fied requirement for these same sites in activating $\beta$-globin transcription in vitro in the absence of the enhancer [Emerson et al. 19891]. Such a model predicts that mutations affecting the stability of these promoter-enhancer interactions (and hence, $\beta^{\prime}$-globin transcription! would have reciprocal effects on expression of the linked $\epsilon^{\prime}$-globin gene in definitive cells (Gallarda et al. 1989a). Figures 2D and 3 demonstrate that the level of $\epsilon^{\prime}$-globin transcription detected was inversely proportional to the severity of the effect of the mutation on $\beta^{\prime}$-globin transcription. These data clearly indicate that any inactivating mutation within the SSE disrupts a finely balanced equilibrium existing between the two globin gene promoters and the $\beta / \epsilon$ enhancer and that the resulting new equilibrium state is reflected by the relative activity of the adult promoter. Therefore, NF-E 4 and $\beta C T F$, by virtue of their direct effect on $\beta$-globin gene transcription, appear to have the additional indirect effect of suppressing $\epsilon$-globin expression. It is quite likely, however, that even though NF-E4 and $\beta C T F$ are key components of the promoter competition mechanism, other factors also contribute to formation of stable promoter-enhancer complexes; this is strongly supported by the reciprocal effects on $\beta^{\prime}$ - versus $\epsilon^{\prime}$-globin expression produced by the $\beta P(-$ TFIID) and $\beta \mathrm{P}(-\mathrm{AP} 2)$ mutations (Fig. 3).

Surprisingly, mutation of the $\beta C T F$ site produced a more severe effect on $\beta^{\prime}$-globin transcription than the 2.25 -fold decrease reported previously for a $5^{\prime}$ deletion mutation [to $-58 \mathrm{bp}$, removing both the AP-2- and $\beta C T F-b i n d i n g$ sites of the SSE (Jackson et al. 1989)]. This disparity is likely attributable to the presence (in the constructs analyzed herel of the $\epsilon^{\prime}$-globin gene actively competing with the adult gene for activation by the enhancer; this competition would be expected to accentuate the effects of an inactivating mutation in the $\beta$-globin promoter. Interestingly, the present results more closely parallel the in vitro transcription analysis of the identical -58-bp deletion construct, even though the enhancer is not active in this assay (Emerson et al. 1989|. This may suggest that the enhancer, in the absence of competition from the linked embryonic gene, is capable of complementing a partial deletion of the $\beta$-globin promoter.

Another prediction of the promoter competition model was that while inactivating the $\beta$-globin gene promoter, certain SSE mutations would still result in formation of a stable SSE-enhancer complex land therefore retain the ability to suppress $\epsilon$-globin transcription) (Gallarda et al. 1989a). Such a state was envisaged as mimicking that present in HD3 cells prior to differentiation induction: one committed to definitive erythropoiesis, but lacking NF-E4 binding activity and therefore unable to transcribe the adult $\beta$-globin gene /Gallarda et al. 1989a). None of the SSE mutations examined gave this result, although the $\beta P(N F-E 4 / \epsilon \mathrm{P})$ mutation could be interpreted in this fashion on the basis of its effect in transfected primitive cells (Fig. 4). This may indicate that additional regulatory elements are missing from these constructs or that the chromatin context of the endogenous genes also contributes/through some currently undefined mechanism) to the promoter equilibrium.

\section{Similarities and differences between human and chicken $\beta$-like globin gene switching}

Regulatory schemes analogous to the promoter competition model have recently been invoked to explain aspects of developmental control in the human $\beta$-like globin gene locus (for review, see Evans et al. 1990; Orkin 1990; Patient 1990; Townes and Behringer 1990, Whitelaw 1990|. Of central importance to these models is a regulatory domain, termed the locus control region (LCR; Orkin 1990), which was originally identified as a series of strong tissue-specific DNase I hypersensitive sites located $50-65 \mathrm{~kb} 5^{\prime}$ to the most distant $(\beta)$ globin gene that it regulates (Tuan and London 1984; Tuan et al. 1985; Forrester et al. 1986). The ability of the LCR (and some individual elements within it) to direct copy number-dependent and position-independent erythroid expression of linked genes in transgenic mice and murine erythroleukemia cells suggests that it not only functions as a tissue-specific enhancer but also is capable of altering local chromatin structure (Grosveld et al. 1987; van Assendelft et al. 1989; Fraser et al. 1990; Caterina et al. 1991 and references therein), a view supported by analysis of naturally occurring deletions in this region (Forrester et al. 1990).

The LCR also appears to be involved in the stage-specific regulation of $\beta$-like globin gene switching in humans. Based principally on analysis of the human locus in transgenic mice, competition is thought to occur between globin promoters for interaction with the multiple regulatory elements within the LCR, rather than for a single enhancer as in chickens; relatively weak enhancers located proximal to the genes likely contribute further to regulation of the cluster (Behringer et al. 1987, Bodine and Ley 1987; Kollias et al. 1987; Trudel et al. 1987; Antoniou et al. 1988). Recent evidence suggests that the human embryonic $\epsilon$ - and fetal ${ }^{\mathrm{G}} \gamma$ - and ${ }^{\mathrm{A}} \gamma$-globin ( $\beta$-like) genes interact autonomously with the LCR and achieve appropriate developmental stage specificity through proximal silencer elements (Cao et al. 1989; Lindenbaum and Grosveld 1990; Raich et al. 1990; Shih et al. 1990; Dillon and Grosveld 1991). The human adult $\beta$-globin gene, however, appears to be competitively suppressed at the fetal stage by the $\gamma$-globin genes and is activated only when the fetal genes are silenced and the LCR becomes available to interact with the adult promoter (Behringer et al. 1990; Enver et al. 1990; Hanscombe et al. 1991). This is in contrast to what has 
been shown for the chicken adult $\beta$-globin gene, which is autonomously regulated activated only in definitive cells), whereas the chicken embryonic $\epsilon$-globin gene is suppressed in these cells by competition with the adult gene for the shared enhancer (Choi and Engel 1988 and this report). Therefore, the underlying mechanisms are similar between the two species, and yet the developmental stages that appear to be dependent on autonomous or competitive regulation are reversed.

A significant difference between each species is the relative positions of the principle regulatory elements: The human LCR is located a considerable distance upstream of the locus, whereas the chicken enhancer is located midway between the $\beta$ - and $\epsilon$-globin genes. The chicken $\beta / \epsilon$ enhancer shares many of the attributes of a LCR (Reitman et al. 1990) and has been proposed to be part of a chicken LCR that was translocated to its present intergenic position in the gene duplication and conversion event that gave rise to the unusual $3^{\prime}$ location of the embryonic $\epsilon$-globin gene / the $5^{\prime} \rightarrow 3^{\prime}$ order of globin genes in other vertebrate species generally parallels their developmental order of expression; Roninson and Ingram 1982; Dodgson et al. 1983; Bunn and Forget 1986). Perhaps, significantly, the gene-proximal regulatory elements in the human $\beta$-like globin gene locus [including an enhancer located $3^{\prime}$ to the adult $\beta$-globin gene; (Behringer et al. 1987; Bodine and Ley 1987; Kollias et al. 1987; Trudel et al. 1987; Antoniou et al. 1988)] appear to be dependent on activation by the LCR (Grosveld et al. 1987; Enver et al. 1989), leading to the tentative conclusion that the chicken $\beta / \epsilon$ enhancer fulfills the same functional role as the LCR. The possibility remains, however, that the $5^{\prime}$ distal hypersensitive sites that have been identified recently in the chicken locus are also part of a LCR (Reitman and Felsenfeld 1990). Alternatively, these hypersensitive sites may only retain the ability to affect chromatin structure and lack the enhancer activity associated with the $\beta / \epsilon$ enhancer; this would leave the stage-specific regulation of the genes within the cluster dependent on either autonomous or competitive interactions between the promoters and the single enhancer. Such a potential separation of activities has been demonstrated by mutagenesis of the human $\beta$-globin LCR (Caterina et al. 1991; Talbot and Grosveld 1991) and occurs naturally in the chicken lysozyme locus (Stief et al. 1989; Phi-Van et al. 1990). If only a single enhancer regulates the entire $\beta$-like globin gene locus in chickens, the stage specificity of the $\rho$ - and $\beta^{{ }^{H}}$-globin genes (by analogy to the $\beta$ - and $\epsilon$-globin genes) would likely be controlled through the stage-specific interactions of their promoters with that enhancer. Given the sequence similarities and differences between each promoter [the $\rho$ - and $\epsilon$-globin promoters are identical, whereas the $\beta^{\mathrm{H}}$-globin promoter contains several sequence differences that would be predicted to bind factors not present in the other elements (Plumb et al. 1986; Engel et al. 1989; Perkins et al. 1989; Stuve and Myers 1990)|, this is an appealing possibility. Support for this model comes from transfections in which the $\beta^{\prime}$-globin gene promoter NF-E4 site was altered to create the bind- ing site found in the analogous position of the $\epsilon$-globin (or $\rho$-globin) promoter [in plasmid $\mathrm{p}^{\prime} \epsilon^{\prime}(+) \cdot \beta \mathrm{P}(\mathrm{NF}-\mathrm{E} 4 /$ $\epsilon \mathrm{P})$; Fig. $1 \mathrm{~B}]$; this mutation altered the stage specificity of expression of the $\beta^{\prime}$-globin gene, presumably by allowing the binding of an $\epsilon$-globin promoter factor to the SSE (Fig. 4).

On the basis of the proposed competitive interactions between the human fetal and adult $\beta$-like globin genes, one might anticipate the identification of mutations that alter the developmental expression patterns of these genes. A variety of naturally occurring mutations in humans have been reported that result in abnormally elevated levels of fetal ${ }^{\mathrm{G}} \boldsymbol{\gamma}$ - and/or ${ }^{\mathrm{A}} \boldsymbol{\gamma}$-globin in the adult (termed hereditary persistence of fetal hemoglobin, or HPFH) (Weatherall et al. 1989). Many of these HPFH individuals have large deletions in the locus including the adult $\beta$-globin gene. Another class of HPFH individuals has been correlated with point mutations within the fetal globin gene promoters, and it has been proposed that these result in either increased or decreased binding of transcription factors, thereby giving rise to aberrant transcriptional activity (Weatherall et al. 1989). The results reported here, showing that disruption of the binding site for a single transcription factor can profoundly alter the developmental expression pattern of the associated globin genes, provides an experimental foundation on which to anchor such a HPFH hypothesis. Interestingly, several HPFH mutations involving the $-200 \mathrm{bp}$ region of the $\gamma$-globin promoters appear to create sequences similar to the NF-E4-binding site in the SSE (Weatherall et al. 1989). Mutations in this region have been proposed to act by creating a new binding site for (or increasing the binding affinity of) transcription factor Spl, thereby allowing transcription of fetal $\gamma$-globin in the adult (Sykes and Kaufman 1989). Perhaps significantly, NF-E4 and Spl share sequence specificity for the NF-E4-binding site in the chicken $\beta$-globin SSE, although NF-E4 appears to bind with substantially higher affinity (Lewis et al. 1988; Emerson et al. 1989; Gallarda et al. 1989a; Yang et al. 1991). If humans express a homolog of NF-E4 in an adult stage-specific manner, the binding of this factor to the fetal promoters could account for HPFH in these cases.

Although promoter competition clearly plays a fundamental role in chicken $\beta / \epsilon$-globin switching, it is likely that fully regulated expression is dependent on the in terplay of a variety of additional determinants. These include elements that control position and copy number dependence as well as other transcription factors which, although not as demonstrably associated with stage-specific expression as are NF-E4 and $\beta C T F$, may vary in concentration and/or activity during erythropoiesis and thereby contribute significantly to globin gene expression. The importance of promoter competition for $\beta / \epsilon-$ globin switching, however, prompts speculation as to its involvement in other regulatory systems. Promoter competition is conceptually related to the increasingly well- characterized phenomenon of multiple enhancers regulating a single gene in a temporal or tissue-specific manner. This has been examined extensively in the seg- 
mentation genes of Drosophila, where the characteristic striped expression patterns of the primary pair-rule genes are believed to be dependent on multiple enhancer elements, each of which is responsive to the overlapping gradients of transcription factors expressed in the developing embryo by the maternal coordinate and gap genes. Differential activation of the pair-rule promoters by their associated enhancers (either by autonomous or competitive means) is presumed to lead to spatially restricted expression of the genes (Carroll 1990, Pankratz and Jäckle 1990). An analogous situation may exist for murine Hox genes (Whiting et al. 1991) and is certainly true for the the human $\beta$-globin LCR as discussed above). These examples represent the reverse of the chicken $\beta / \epsilon$-globin switching paradigm, where multiple promoters compete for a single enhancer. We suspect that competitive interactions between proximal and distal cis-regulatory elements will be involved in a variety of other developmentally complex expression patterns during embryogenesis.

\section{Materials and methods}

\section{Plasmid constructions}

Techniques used below were performed essentially as detailed previously (Ausubel et al. 1989). The mutated $\beta$-globin gene promoter constructs described here were derived from $\mathrm{p} \beta^{*} \epsilon^{*}(\Delta-820 /-112)$ (Choi and Engel 1988), which contains $\sim 8$ $\mathrm{kb}$ of contiguous chicken genomic DNA extending from a SmaI site at $-112 \mathrm{bp}$ of the $\beta$-globin promoter (relative to the cap site at +1 ) to a HindIII site lying $\sim 1.6 \mathrm{~kb} 3^{\prime}$ to the $\epsilon$-globin gene polyadenylation sequence; the asterisk refers to an 8 -bp ClaI linker inserted at a different position in the third exon of each gene (Choi and Engel 1986, 1988). $\mathrm{p} \beta^{*} \epsilon^{*}(+)$ is identical to this construct, except that it contains additional 5 ' sequences extending to approximately -820 bp of the $\beta$-globin promoter (Choi and Engel 1988). To prepare $\beta$-globin promoter mutations, the $-112-(X b a I)$ to $-11-b p(E a g I)$ fragment of $p \beta^{*} \epsilon^{*}(\Delta-820$ / -112 ) was cloned into the $X b a I-E a g I$ polylinker sites of a modified pGEM-3 vector (Promega). Four double-stranded oligonucleotides were synthesized, each containing clustered mutations within one of the four consensus transcription factorbinding sites (Gallarda et al. 1989a) of the $\beta$-globin SSE. These oligonucleotides were substituted individually into the wildtype XbaI-EagI promoter fragment fusing either naturally occurring restriction enzyme sites or an artificially introduced PvuI site at $-36 \mathrm{bp}$ ) to create promoters mutated at single protein-binding sites; the wild-type promoter of $p \beta^{*} \epsilon^{*}(\Delta-820 /$ -112 ) was then replaced, and the results were verified by DNA sequencing. Figure $1 \mathrm{~B}$ summarizes the sequences of these modified promoters. $\left.p \beta^{*} \epsilon^{*}(+) \cdot \beta P \mid-15\right)$ was generated through deletion of the $5^{\prime}$ end of the $\beta$-globin promoter in $p \beta^{*} \epsilon^{*} \mid \Lambda-820$ / -112 ) to -15 bp by digestion with $X b a \mathrm{I}$ and EagI, followed by blunt-end religation; the $770-\mathrm{bp} B g / I I-B a m H I$ fragment from $\mathrm{pA}_{3} \mathrm{RSV}_{400} \mathrm{LUC}$, containing a head-to-tail trimer of the SV40 early and late polyadenylation signals, was ligated in the sense orientation into the polylinker $5^{\prime}$ to the $\beta$-globin promoter deletion in this construct to inhibit inappropriate transcriptional initiation from flanking plasmid sequences (Maxwell et al. 1989).

To prepare modified test constructs for use in the RNA/PCR assay, a 37-bp SmaI-ClaI fragment from the polylinker of CLA12NCO (Hughes et al. 1987) was inserted as an inverted repeat into the ClaI site of pSP71 (Promega), regenerating a SmaI site between the two repeats (pADP37). The ClaI fragment spanning the $\beta^{*}$ and $\epsilon^{\star}$ third exons of $\mathrm{p} \beta^{*} \epsilon^{\star}(\Delta-820 /-112)$ was flushed, inserted into the SmaI site of pADP37, and reisolated as a ClaI fragment containing half of the inverted repeat at each end. Reinsertion of this fragment into $p \beta^{*} \epsilon^{*} \mid+1$ and $\mathrm{p} \beta^{*} \epsilon^{*}(\Delta-820 /-112)$ generated $\left.\mathrm{p} \beta^{\prime} \epsilon^{\prime}|+| \cdot \beta \mathrm{P} \mid-820\right)$ and $p \beta^{\prime} \epsilon^{\prime}|+| \cdot \beta P(-112)$, respectively (each gene now being marked by an insert of 46 bp compared with the wild-type genes; Fig. 1A). An identical process was followed to mark the derivatives of $\mathrm{p} \beta^{*} \epsilon^{*}(\Delta-820 /-112)$ containing mutations in the $\beta^{*}$-globin promoter.

The internal control construct $p \beta^{\prime \prime} \epsilon^{\prime \prime}|++|$ was derived by modification of $\mathrm{p} \beta^{*} \epsilon^{*}|++|$ (Choi and Engel 1988), which is identical to $p \beta^{*} \epsilon^{*}(+)$, except for the tandem duplication of a 1.7-kb Sacl-BamHI fragment (containing the enhancer) located between the two genes. The marked $\epsilon^{\prime \prime}$ gene was prepared by ClaI partial digestion and insertion of a 76-bp ClaI fragment into the $\epsilon^{*}$ third exon ClaI site of $\mathrm{p}^{*} \epsilon^{*}(-+)$. This polylinker fragment was isolated from CLA12NCO, which had been digested with NcoI and Sall, flushed, and religated. To generate $\beta^{\prime \prime}$, CLA12NCO was cut with XbaI, flushed, and religated; the 37bp fragment used to create $\beta^{\prime}$ and $\epsilon^{\prime}$ above was flushed and inserted into the flushed HindIII site of this construct in the opposite orientation as it is present in CLAl2NCO (this provides the same primer-binding sequence in $\beta^{\prime \prime}$ as in $\left.\beta^{\prime}\right)$. The entire ClaI polylinker fragment was then ligated into the ClaI site of pGEM-7Zf $\mid+$ | (Promega), oriented with the BamHI site nearest the $T 7$ promoter. Finally, this construct was cut with HindIII and SacI, and a 43-bp double-stranded oligonucleotide of random sequence (flanked by SacI-ClaI and HindIII sites) was inserted. The resulting 76-bp ClaI fragment was ligated into $\beta^{*}$ after ClaI partial digestion of $\mathrm{p} \beta^{*} \epsilon^{\prime} \mid++1$, generating $\left.p \beta^{\prime \prime} \epsilon^{\prime \prime}\right)++$ ) (Fig. 1A).

The sequences of the resulting $\beta^{\prime}, \epsilon^{\prime}, \beta^{\prime \prime}$, and $\epsilon^{\prime \prime}$ third exon inserts (sense strand), including all sequences not present in the wild-type genes, are as follows (nucleotides to which the $3^{\prime}$ PCR primers anneal are underlined): $\beta^{\prime}$ :CATCGATAAGCTTGGCTGCAGGTCGACTCTAGAGGATCCCCCGATG; $\epsilon^{\prime}:$ CAT CGGGGGATCCTCTAGAGTCGACCTGCAGCCAAGCTT ATCGATG; $\quad \beta^{\prime \prime}:$ CATCGATGCACGAGACTGTCAGGATG TACGACTGTTCTCAGCTTGGCTGCAGGTCGACTCTAGAGGATCCCCAGCTTATCGATG; $\epsilon^{\prime \prime}$ :CATCGATTCTAGA CCACTGTGGCCAGGCGGTAGCTGGGACGTGCAGCCGACCACCATGTCGACCTGCAGCCAAGCTTATCGATG.

\section{Transient transfections}

The ts34AEV-transformed HD3 cell line was cultured and induced to differentiate essentially as has been reported (Beug et al. 1982; Zenke et al. 1988). Transfections were performed using a small-scale version of the DEAE-dextran procedure described previously (Choi and Engel 1988). For transfection of $2 \times 10^{6}$ cells, $1.67 \mu \mathrm{g}$ of each plasmid was used; all other volumes were reduced by $50 \%$ (Choi and Engel 1988). Differentiation conditions were modified to include $15 \mu \mathrm{M} \mathrm{H} 7$ (Seikagaku America), an inhibitor of cyclic nucleotide-dependent protein kinases and protein kinase $C_{i}$ this appears to improve the extent of differentiation by inhibiting the phosphorylation and transformation activity of v-erbA (Glineur et al. 1990). Thirty-six hours after induction of differentiation, transfected cells were collected and total RNA was prepared (Chomczynski and Sacchi 1987).

Primitive erythrocytes from 4-day chicken embryos were isolated and cultured essentially as detailed previously (Hesse et al. 1986; Lieber et al. 1987). Transfections were performed using the cationic lipopolyamine dioctadecylamidoglycyl spermidine 
[Transfectam Reagent, Promega (Behr et al. 1989)]. For $2 \times 10^{6}$ cells in $1.5 \mathrm{ml}$ of medium, $1 \mu \mathrm{g}$ of each plasmid plus $2 \mu \mathrm{l}$ of lipid/ $\mu$ g of DNA were transfected following the manufacturer's recommendations for medium containing serum. DNA concentrations were optimized to be within the linear expression range (data not shown). The cells were then cultured for $48 \mathrm{hr}$ at $37^{\circ} \mathrm{C}$ in the absence of $\mathrm{CO}_{2}$ (without replacing the medium) prior to preparation of total RNA as described above.

\section{RNA/PCR assay}

Total cellular RNA from $\sim 200$ cells was denatured at $80^{\circ} \mathrm{C}$ for 5 min and used as template for cDNA synthesis in a $40-\mu l$ reaction containing 1.2 units of $\mathrm{AEV}$ reverse transcriptase $(\mathrm{RT})$ (Promega), $1 \times \mathrm{RT} / \mathrm{PCR}$ buffer $\left[20 \mathrm{~mm}\right.$ Tris $-\mathrm{HCl}\left(\mathrm{pH} 8.4\right.$ at $\left.22^{\circ} \mathrm{C}\right)$, $50 \mathrm{~mm} \mathrm{KCl}, 2.5 \mathrm{~mm} \mathrm{MgCl} 2,100 \mu \mathrm{g} / \mathrm{ml}$ of BSA], $1 \mathrm{~mm}$ of each dNTP, $100 \mathrm{ng}$ of oligo $(\mathrm{dT})_{15}$, and 40 units of RNasin ribonuclease inhibitor (Promega). The reaction was incubated for 10 min at $22^{\circ} \mathrm{C}, 90 \mathrm{~min}$ at $42^{\circ} \mathrm{C}$, and $10 \mathrm{~min}$ at $95^{\circ} \mathrm{C}$. Reverse transcriptase in cxcess of the amount used here was found to inhibit the subsequent PCR reaction (data not shown). The entire cDNA preparation was then amplified in a 200- $\mu$ l PCR reaction containing 8 units of Taq polymerase (Promega), $1 \times \mathrm{RT}$ / PCR buffer, $0.1 \%$ Triton X-100, $8 \mu \mathrm{Ci}\left[\alpha^{-32} \mathrm{P}\right] \mathrm{dCTP}$ (3000 Ci/ mmole; ICN), and 80 pmoles of each $\beta$ - or $\epsilon$-specific primer (see below) and covered with $50 \mu \mathrm{l}$ of light white mineral oil. Amplifications were carried out in a Perkin-Elmer/Cetus DNA thermal cycler with the following temperature profile: an initial denaturation at $95^{\circ} \mathrm{C}$ for $2 \mathrm{~min}$, then repeating cycles of $95^{\circ} \mathrm{C}$ for $30 \mathrm{sec}, 50$ or $60^{\circ} \mathrm{C}$ for $30 \mathrm{sec}$ (see below), and $72^{\circ} \mathrm{C}$ for $30 \mathrm{sec}$. Aliquots of $50 \mu \mathrm{l}$ were removed (from below the mineral oil) during the cycling reaction every three cycles over the range empirically determined to be toward the end of the exponential phase of amplification /generally 22-31 cycles for $\beta^{\prime}+\beta^{\prime \prime}$ and 28-37 cycles for $\epsilon^{\prime}+\epsilon^{\prime \prime} \mid$. After precipitation of the amplified DNA and resuspension in sequencing dye $195 \%$ formamide, $0.01 \%$ bromphenol blue), $25 \%$ of each sample was heated at $90^{\circ} \mathrm{C}$ for $5 \mathrm{~min}$ and electrophoresed on a denaturing $6 \%$ polyacrylamide $/ 8 \mathrm{M}$ urea sequencing gel with wedge spacers. The $\beta^{\prime} / \beta^{\prime \prime}$ and $\epsilon^{\prime} / \epsilon^{\prime \prime}$ ratios were determined by quantitation of incorporated radioactivity using a Molecular Dynamics 400A PhosphorImager System (Johnston et al. 1990).

PCR primers used above are as follows (annealing temperatures are in parentheses): $5^{\prime} \beta\left(50^{\circ} \mathrm{C}\right): 5^{\prime}$-TCTCCCAACTGTCCGAAC-3 $3^{\prime} ; 3^{\prime} \beta^{\prime} /^{\prime \prime}\left(50^{\circ} \mathrm{C}\right): 5^{\prime}$-ATCCTCTAGAGTCGACCT-3'; $\left.5^{\prime} \epsilon\left(60^{\circ} \mathrm{C}\right): 5^{\prime}-\mathrm{GGGTCCGTGCTCATGGTAAG-}-3^{\prime} ; 3^{\prime} \epsilon^{\prime}\right)^{\prime \prime}\left(60^{\circ} \mathrm{C}\right)$ : 5'-CGATAAGCTTGGCTGCAGGT-3' .

\section{Acknowledgments}

We gratefully acknowledge the assistance and advice of our laboratory colleagues. In particular, we thank L.J. Ko for insightful comments, M.W. Leonard for technical help and critical reading of the manuscript, S.J. Stamler for invaluable expertise in tissue culture, and M. Yamamoto for first suggesting a role for NF-E4 in HPFH. Transfectam Reagent used in these studies was generously provided by Promega Corporation. This work was supported in part by a National Institute of General Medical Sciences (NIGMS) National Research Service Award (NRSA) training grant to Northwestern University (K.P.F.) and by a grant from the National Institutes of Health (J.D.E.).

The publication costs of this article were defrayed in part by payment of page charges. This article must therefore be hereby marked "advertisement" in accordance with 18 USC section 1734 solely to indicate this fact.

\section{References}

Antoniou, M., E. deBoer, G. Habets, and F. Grosveld. 1988. The human $\beta$-globin gene contains multiple regulatory regions: Identification of one promoter and two downstream enhancers. EMBO /. 7: 377-384.

Ausubel, F.M., R. Brent, R.E. Kingston, D.M. Moore, J.G. Seidman, J.A. Smith, and K. Struhl. 1989. Current protocols in molecular biology. Greene Publishing Associates/Wiley-Interscience, New York.

Behr, J.-P., B. Demeneix, J.-P. Loeffler, and J. Perez-Mutul. 1989. Efficient gene transfer into mammalian primary endocrine cells with lipopolyamine-coated DNA. Proc. Natl. Acad. Sci. 86: 6982-6986.

Behringer, R.R., R.E. Hammer, R.L. Brinster, R.D. Palmiter, and T.M. Townes. 1987. Two 3' sequences direct adult erythroid-specific expression of human $\beta$-globin genes in transgenic mice. Proc. Nat1. Acad. Sci. 84: 7056-7060.

Behringer, R.R., T.M. Ryan, R.D. Palmiter, R.L. Brinster, and T.M. Townes. 1990. Human $\gamma$ - to $\beta$-globin gene switching in transgenic mice. Genes \& Dev. 4: 380-389.

Beug, H., G. Doederlien, C. Freudenstein, and T. Graf. 1982. Erythroblast cell lines transformed by a temperature-sensitive mutant of avian erythroblastosis virus: A model system to study erythroid differentiation in vitro. I. Cell. Physiol. (Suppl.) 1: 195-207.

Bodine, D.M. and T. Ley. 1987. An enhancer element lies 3' to the human ${ }^{\mathrm{A}} \gamma$-globin genc. EMBO I. 6: 2997-3004.

Brotherton, T.W., D.H.K. Chui, J. Gauldie, and M. Patterson. 1979. Hemoglobin ontogeny during normal mouse fetal development. Proc. Natl. Acad. Sci. 76: 2853-2857.

Brown, J.L. and V.M. Ingram. 1974. Structural studies on chick embryonic hemoglobins. I. Biol. Chem. 249: 3960-3972.

Bruns, G.A.P. and V.M. Ingram. 1973. The erythroid cells and haemoglobins of the chick embryo. Philos. Trans. R. Soc. Lond. B. Biol. Sci. 265: 225-305.

Buckle, R., M. Balmer, A. Yenidunya, and J. Allan. 1991. The promoter and enhancer of the inactive chicken $\beta$-globin gene contains precisely positioned nucleosomes. Nucleic Acids Res. 19: 1219-1226.

Bunn, H.F. and B.G. Forget. 1986. Hemoglobin: Molecular, genetic and clinical aspects. W.B. Saunders, Philadelphia, PA.

Camp, T.A., J.O. Rahal, and K.E. Mayo. 1991. Cellular localization and hormonal regulation of follicle-stimulating hormone and luteinizing hormone receptor messenger RNAs in the rat ovary. Mol. Endocrinol. 5: 1405-1417.

Cao, S.X., P.D. Gutman, H.P.G. Dave, and A.N. Schechter. 1989. Identification of a transcriptional silencer in the 5 flanking region of the human $\epsilon$-globin gene. Proc. Natl. Acad. Sci. 86: 5306-5309.

Carroll, S.B. 1990. Zebra patterns in fly embryos: Activation of stripes or repression of interstripes? Cell 60: 9-16.

Caterina, J.J., T.M. Ryan, K.M. Pawlik, R.D. Palmiter, R.L. Brinster, R.R. Behringer, and T.M. Townes. 1991. Human $\beta$-globin locus control region: Analysis of the $5^{\prime}$ DNase I hypersensitive site HS 2 in transgenic mice. Proc. Natl. Acad. Sci. 88: 1626-1630.

Chapman, B.S. and A.J. Tobin. 1979. Distribution of developmentally regulated hemoglobins in embryonic erythroid populations. Dev. Biol. 69: 375-387.

Chelly, J., J.-C. Kaplan, P. Maire, S. Gautron, and A. Kahn. 1988. Transcription of the dystrophin gene in human muscle and non-muscle tissues. Nature 333: 858-860.

Choi, O.-R. and J.D. Engel. 1986. A 3' enhancer is required for temporal and tissue-specific transcriptional activation of the chicken adult $\beta$-globin gene. Nature 323: 731-734. 
1988. Developmental regulation of $\beta$-globin gene switching. Cell 55: 17-26.

Chomczynski, P. and N. Sacchi. 1987. Single-step method of RNA isolation by acid guanidinium thiocyanate-phenolchloroform extraction. Anal. Biochem. 162: 156-159.

Clark, S.P., C.D. Lewis, and G. Felsenfeld. 1990. Properties of BGP1, a poly(dG)-binding protein from chicken erythrocytes. Nucleic Acids Res. 18: 5119-5126.

Dillon, N. and F. Grosveld. 1991. Human $\gamma$-globin genes silenced independently of other genes in the $\beta$-globin locus. Nature 350: 252-254.

Dodgson, J.B., S.J. Stadt, O.-R. Choi, M. Dolan, H.D. Fisher, and J.D. Engel. 1983. The nucleotide sequence of the embryonic chicken $\beta$-type globin genes. I. Biol. Chem. 258: 1268512692.

Dolan, M., B.J. Sugarman, J.B. Dodgson, and J.D. Engel. 1981. Chromosomal arrangement of the chicken $\beta$-type globin genes. Cell 24: 669-677

Dolan, M., J.B. Dodgson, and J.D. Engel. 1983. Analysis of the adult chicken $\beta$-globin gene. I. Biol. Chem. 258: 3983-3990.

Emerson, B.M. and G. Felsenfeld. 1984. Specific factor conferring nuclease hypersensitivity at the $5^{\prime}$ end of the chicken adult $\beta$-globin gene. Proc. Natl. Acad. Sci. 81:95-99.

Emerson, B.M., C.D. Lewis, and G. Felsenfeld. 1985. Interaction of specific nuclear factors with the nuclease-hypersensitive region of the chicken adult $\beta$-globin gene: Nature of the binding domain. Cell 41:21-30.

Emerson, B.M., J.M. Nickol, P.D. Jackson, and G. Felsenfeld. 1987. Analysis of the tissue-specific enhancer at the $3^{\prime}$ end of the chicken adult $\beta$-globin gene. Proc. Natl. Acad. Sci. 84: 4786-4790

Emerson, B.M., J.M. Nickol, and T.C. Fong. 1989. Erythroidspecific activation and derepression of the chick $\beta$-globin promoter in vitro. Cell 57: 1189-1200.

Engel, J.D., O.-R.B. Choi, D.J. Endean, K.P. Foley, J.L. Gallarda, and Z. Yang. 1989. Genetics and biochemistry of the embryonic to adult switch in the chicken $\epsilon$ - and $\beta$-globin genes. In Hemoglobin switching part A: Transcriptional regulation \{ed. G. Stamatoyannopoulos and A.W. Nienhuis।, pp. 89103. Alan R. Liss, New York.

Engel, J.D., K.M. George, L.J. Ko, J.M. Kornhauser, M.W. Leonard, P. Ting, and M. Yamamoto. 1991. Transcription factor regulation of hematopoictic lineage cells. Semin. Hematol. 28: $158-169$

Enver, T., A.J. Ebens, W.C. Forrester, and G. Stamatoyannopoulos. 1989. The human $\beta$-globin locus activation region alters the developmental fate of a human fetal globin gene in transgenic mice. Proc. Natl. Acad. Sci. 86: 7033-7037.

Enver, T., N. Raich, A.J. Ebens, T. Papayannopoulou, F. Costantini, and G. Stamatoyannopoulos. 1990. Developmental regulation of human fetal-to-adult globin gene switching in transgenic mice. Nature 344: 309-313.

Evans, T., M. Reitman, and G. Felsenfeld. 1988. An erythrocytespecific DNA-binding factor recognizes a regulatory sequence common to all chicken globin genes. Proc. Natl. Acad. Sci. 85: 5976-5980.

Evans, T., G. Felsenfeld, and M. Reitman. 1990. Control of globin gene transcription. Annu. Rev. Cell Biol. 6: 95-124.

Forrester, W.C., C. Thompson, J.T. Elder, and M. Groudine. 1986. A developmentally stable chromatin structure in the human $\beta$-globin gene cluster. Proc. Natl. Acad. Sci. 83: $1359-1363$

Forrester, W.C., E. Epner, M.C. Driscoll, T. Enver, M. Brice, T. Papayannopoulou, and M. Groudine. 1990. A deletion of the human $\beta$-globin locus activation region causes a major alteration in chromatin structure and replication across the en- tire $\beta$-globin locus. Genes \& Dev. 4: 1637-1649

Fraser, P., J. Hurst, P. Collis, and F. Grosveld. 1990. DNase I hypersensitive sites 1,2 and 3 of the human $\beta$-globin dominant control region direct position-independent expression. Nucleic Acids Res. 18: 3503-3508.

Gallarda, J.L., K.P. Foley, Z. Yang, and J.D. Engel. 1989a. The $\beta$-globin stage selector element factor is erythroid-specific promoter/enhancer binding protein NF-E4. Genes \& Dev. 3: $1845-1859$.

Gallarda, J.L., Z. Yang, D.J. Endean, K.P. Foley, and J.D. Engel. 1989 b. cis and trans determinants of chicken $\beta$-globin transcription. In Tissue specific gene expression /ed. R. Renkawitzl, pp. 103-121. VCH Publishers, Weinheim, Germany.

Gilliland, G., S. Perrin, K. Blanchard, and H.F. Bunn. 1990a. Analysis of cytokine mRNA and DNA: Detection and quantitation by competitive polymerase chain reaction. Proc. Natl. Acad. Sci. 87: 2725-2729

Gilliland, G., S. Perrin, and H.F. Bunn. 1990b. Competitive PCR for quantitation of mRNA. In PCR protocols: A guide to methods and applications (ed. M.A. Innis, D.H. Gelfand, J.J. Sninsky, and T.J. Whitel, pp. 60-69. Academic Press, San Diego, CA.

Glineur, C., M. Zenke, H. Beug, and J. Ghysdacl. 1990. Phosphorylation of the v-erbA protein is required for its function as an oncogene. Genes \& Dev. 4: 1663-1676.

Grosveld, F., G.B. van Assendelft, D.R. Greaves, and G. Kollias. 1987. Position-independent, high-level expression of the human $\beta$-globin gene in transgenic mice. Cell 51: 975-985

Groudine, M., M. Peretz, and H. Weintraub. 1981. Transcriptional regulation of hemoglobin switching in chicken embryos. Mol. Cell. Biol. 1: 281-288.

Hanscombe, O., D. Whyatt, P. Fraser, N. Yannoutsos, D Greaves, N. Dillon, and F. Grosveld. 1991. Importance of globin gene order for correct developmental expression. Genes \& Dev. 5: 1387-1394.

Harrison, P.R. 1976. Analysis of erythropoiesis at the molecular level. Nature 262: 353-356.

Hesse, J.E., J.M. Nickol, M.R. Lieber, and G. Felsenfeld. 1986. Regulated gene expression in transfected primary chicken erythrocytes. Proc. Natl. Acad. Sci. 83: 4312-4316.

Hughes, S.H., J.J. Greenhouse, C.J. Petropoulos, and P. Sutrave. 1987. Adaptor plasmids simplify the insertion of foreign DNA into helper-independent retroviral vectors. /. Virol. 61: 3004-3012.

Ingram, V.M. 1972. Embryonic red blood cell formation. Nature 235: 338-339.

Innis, M.A. and D.H. Gelfand. 1990. Optimization of PCRs. In PCR protocols: A guide to methods and applications (ed. M.A. Innis, D.H. Gelfand, J.J. Sninsky, and T.J. White), pp. 3-12. Academic Press, San Diego, CA.

Jackson, P.D., T. Evans, J.M. Nickol, and G. Felsenfeld. 1989. Developmental modulation of protein binding to $\beta$-globin gene regulatory sites within chicken erythrocyte nuclei. Genes \& Dev. 3: 1860-1873.

Johnston, R.F., S.C. Pickett, and D.L. Barker. 1990. Autoradiography using storage phosphor technology. Electrophoresis 11: 355-360.

Kollias, G., J. Hurst, E. deBoer, and F. Grosveld. 1987. The human $\beta$-globin gene contains a downstream developmental specific enhancer. Nucleic Acids Res. 15: 5739-5747.

Lewis, C.D., S.P. Clark, G. Felsenfeld, and H. Gould. 1988. An erythrocyte-specific protein that binds to the poly $(\mathrm{dG})$ region of the chicken $\beta$-globin gene promoter. Genes \& Dev. 2: 863-873.

Lieber, M.R., J.E. Hesse, J.M. Nickol, and G. Felsenfeld. 1987. The mechanism of osmotic transfection of avian embryonic 
erythrocytes: Analysis of a system for studying developmental gene expression. I. Cell Biol. 105: 1055-1065.

Lindenbaum, M.H. and F. Grosveld. 1990. An in vitro globin gene switching model based on differentiated embryonic stem cells. Genes \& Dev. 4: 2075-2085.

Linz, U. 1990. Thermocycler temperature variation invalidates PCR results. BioTechniques 9: 286-293.

Maxwell, I.H., G.S. Harrison, W.M. Wood, and F. Maxwell. 1989. A DNA cassette containing a trimerized SV40 polyadenylation signal which efficiently blocks spurious plasmidinitiated transcription. BioTechniques 7: 276-280.

Melis, M., G. Demopulos, V. Najfeld, J.-W. Zhang, M. Brice, T. Papayannopoulou, and G. Stamatoyannopoulos. 1987. A chromosome 11-linked determinant controls fetal globin expression and the fetal-to-adult globin switch. Proc. Natl. Acad. Sci. 84: 8105-8109.

Nickol, J.M. and G. Felsenfeld. 1988. Bidirectional control of the chicken $\beta$ - and $\epsilon$-globin genes by a shared enhancer. Proc. Natl. Acad. Sci. 85: 2548-2552.

Orkin, S.H. 1990. Globin gene regulation and switching: Circa 1990. Cell 63: 665-672.

Pankratz, M.J. and H. Jäckle. 1990. Making stripes in the Drosophila embryo. Trends Genet. 6: 287-292.

Papayannopoulou, T., M. Brice, and G. Stamatoyannopoulos. 1986. Analysis of human hemoglobin switching in MEL $\times$ human fetal erythroid cell hybrids. Cell 46: 469476.

Patient, R.K. 1990. Control of gene expression: Tissue-specific expression. Curr. Opin. Biotechnol. 1: 151-158.

Perkins, N.D., R.H. Nicolas, M.A. Plumb, and G.H. Goodwin. 1989. The purification of an erythroid protein which binds to enhancer and promoter elements of haemoglobin genes. $\mathrm{Nu}$ cleic Acids Res. 17: 1299-1314.

Phi-Van, L., J.P. von Kries, W. Ostertag, and W.H. Stratling. 1990. The chicken lysozyme $5^{\prime}$ matrix attachment region increases transcription from a heterologous promoter in heterologous cells and dampens position effects on the expression of transfected genes. Mol. Cell. Biol. 10: 2302-2307.

Pine, K.S. and A.J. Tobin. 1976. Hemoglobin synthesis in isolated erythroid colonies from the chick embryo. Dev. Biol. 49: 556-562.

Plumb, M.A., R.H. Nicolas, C.A. Wright, and G.H. Goodwin. 1985. Multiple sequence-specific DNA binding activities are eluted from chicken nuclei at low ionic strengths. Nucleic Acids Res. 13: 4047-4065.

Plumb, M.A., V.V. Lobanenkov, R.H. Nicolas, C.A. Wright, S. Zavou, and G.H. Goodwin. 1986. Characterization of chicken erythroid nuclear proteins which bind to the nuclease hypersensitive regions upstream of the $\beta^{\mathrm{A}}$ - and $\beta^{\mathrm{H}}$ globin genes. Nucleic Acids Res. 14: 7675-7693.

Raich, N., T. Enver, B. Nakamoto, B. Josephson, T. Papyannopoulou, and G. Stamatoyannopoulos. 1990. Autonomous developmental control of human embryonic globin gene switching in transgenic mice. Science 250: 1147-1149.

Reitman, M. and G. Felsenfeld. 1988. Mutational analysis of the chicken $\beta$-globin enhancer reveals two positive-acting domains. Proc. Natl. Acad. Sci. 85: 6267-6271.

- 1990. Developmental regulation of topoisomerase II sites and DNase I-hypersensitive sites in the chicken $\beta$-globin locus. Mol. Cell. Biol. 10: 2774-2786.

Reitman, M., E. Lee, H. Westphal, and G. Felsenfeld. 1990. Siteindependent expression of the chicken $\beta^{\mathrm{A}}$-globin gene in transgenic mice. Nature 348: 749-752.

Roesler, W.J., G.R. Vandenbark, and R.W. Hanson. 1988. Cyclic AMP and the induction of eukaryotic gene transcription. $/$. Biol. Chem. 263: 9063-9066.
Roninson, I.B. and V.M. Ingram. 1982. Gene evolution in the chicken $\beta$-globin cluster. Cell 28: 515-521.

. 1983. Expression and partial DNA sequence of the chicken $\beta^{\mathrm{H}}$-globin gene. J. Biol. Chem. 258: 802-809.

Rupp, R.A.W. and H. Weintraub. 1991. Ubiquitous MyoD transcription at the midblastula transition precedes inductiondependent MyoD expression in presumptive mesoderm of $\mathrm{X}$. laevis. Cell 65: 927-937.

Rupp, R.A.W., R.H. Nicolas, U. Borgmeyer, V.V. Lobanenkov, M.A. Plumb, A.E. Sippel, and G.H. Goodwin. 1988. TGGCA protein is present in erythroid nuclei and binds within the nuclease-hypersensitive sites $5^{\prime}$ of the chicken $\beta^{\mathrm{H}}$ - and $\beta^{\mathrm{A}}$. globin genes. Eur. J. Biochem. 177: 505-511.

Sawadogo, M. and A. Sentenac. 1990. RNA polymerase B (II) and general transcription factors. Annu. Rev. Biochem. 59: $711-$ 754.

Shih, D.M., R.J. Wall, and S.G. Shapiro. 1990. Developmentally regulated and erythroid-specific expression of the human embryonic $\beta$-globin gene in transgenic mice. Nucleic Acids Res. 18: 5465-5472.

Stamatoyannopoulos, G., P. Constantoulakis, M. Brice, S. Kurachi, and T. Papayannopoulou. 1987. Coexpression of embryonic, fetal, and adult globins in erythroid cells of human embryos: Relevance to the cell-lineage models of globin switching. Dev. Biol. 123: 191-197.

Stief, A., D.M. Winter, W.H. Stratling, and A.E. Sippel. 1989. A nuclear DNA attachment element mediates elevated and position-independent gene activity. Nature 341: 343-345.

Stuve, L.L. and R.M. Myers. 1990. A directly repeated sequence in the $\beta$-globin promoter regulates transcription in murine erythroleukemia cells. Mol. Cell. Biol. 10: 972-981.

Sykes, K. and R. Kaufman. 1989. A human gamma globin gene variant binds SP1. In Hemoglobin switching part A: Transcriptional regulation (ed. G. Stamatoyannopoulos and A.W. Nienhuis|, pp. 237-246. Alan R. Liss, New York.

Talbot, D. and F. Grosveld. 1991. The 5' HS2 of the globin locus control region enhances transcription through the interaction of a multimeric complex binding at two functionally distinct NF-E2 binding sites. EMBO I. 10: 1391-1398.

Townes, T.M. and R.R. Behringer. 1990. Human globin locus activation region (LAR): Role in temporal control. Trends Genet. 6: 219-223.

Trudel, M., J. Magram, L. Bruckner, and F. Costantini. 1987. Upstream ${ }^{\mathrm{G}} \gamma$-globin and downstream $\beta$-globin sequences required for stage-specific expression in transgenic mice. Mol. Cell. Biol. 7: 4024-4029.

Tuan, D. and I.M. London. 1984. Mapping of DNase I-hypersensitive sites in the upstream DNA of human embryonic e-globin gene in K562 leukemia cells. Proc. Natl. Acad. Sci. 81: 2718-2722.

Tuan, D., W. Solomon, Q. Li, and I.M. London. 1985. The " $\beta$ like-globin" gene domain in human erythroid cells. Proc. Nat1. Acad. Sci. 82: 6384-6388.

van Assendelft, G.B., O. Hanscombe, F. Grosveld, and D.R. Greaves. 1989. The $\beta$-globin dominant control region activates homologous and heterologous promoters in a tissuespecific manner. Cell 56: 969-977.

Wang, A.M. and D.F. Mark. 1990. Quantitative PCR. In PCR protocols: A guide to methods and applications (ed. M.A. Innis, D.H. Gelfand, J.J. Sninsky, and T.J. White), pp. 70-75. Academic Press, San Diego, CA.

Weatherall, D.J., J.B. Clegg, D.R. Higgs, and W.G. Wood. 1989. The hemoglobinopathies. In The metabolic basis of inherited disease led. J.B. Stanbury, J.B. Wyngaarden, D.S. Fredrickson, J.L. Goldstein, and M.S. Brown), pp. 2281-2239. McGraw-Hill, New York. 
Foley and Engel

Weintraub, H., H. Beug, M. Groudine, and T. Graf. 1982. Temperature-sensitive changes in the structure of globin chromatin in lines of red cell precursors transformed by ts-AEV. Cell 28: 931-940.

Whitelaw, E. 1990. Promoter choice within a gene cluster: A switch of loyalties. BioEssays 12: 283-285.

Whitelaw, E., S.-F. Tsai, P. Hogben, and S.H. Orkin. 1990. Regulated expression of globin chains and the erythroid transcription factor GATA-1 during erythropoiesis in the developing mouse. Mol. Cell. Biol. 10: 6596-6606.

Whiting, J., H. Marshall, M. Cook, R. Krumlauf, P.W.J. Rigby, D. Stott, and R.K. Allemann. 1991. Multiple spatially specific enhancers are required to reconstruct the pattern of Hox-2.6 gene expression. Genes \& Dev. 5: 2048-2059.

Yamamoto, M., L.J. Ko, M.W. Leonard, H. Beug, S.H. Orkin, and J.D. Engel. 1990. Activity and tissue-specific expression of the transcription factor NF-El multigene family. Genes \& Dev. 4: 1650-1662.

Yang, Z., M.W. Leonard, L.J. Ko, K.M. George, M. Yamamoto, and J.D. Engel. 1991. Transcription factors implicated in $\beta$-globin gene switching. In The regulation of hemoglobin switching (ed. G. Stamatoyannopoulos and A.W. Nienhuis), pp. 249-265. Johns Hopkins University Press, Baltimore, $\mathrm{MD}$.

Zenke, M., P. Kahn, C. Disela, B. Vennström, A. Leutz, K. Keegan, M.J. Hayman, H.-R. Choi, N. Yew, J.D. Engel, and H. Beug. 1988. v-erbA specifically suppresses transcription of the avian erythrocyte anion transporter (band 3) gene. Cell 52: $107-119$. 


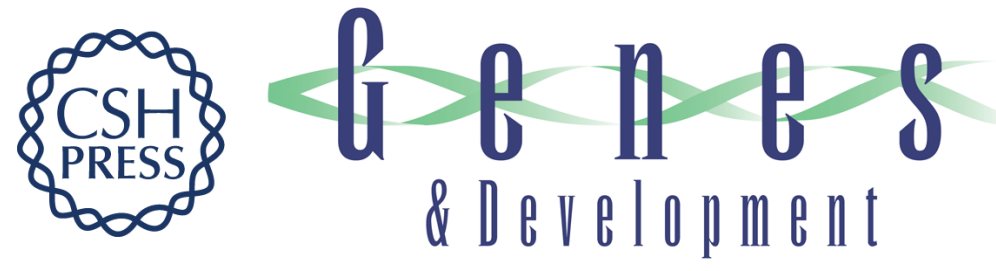

\section{Individual stage selector element mutations lead to reciprocal changes in beta- vs. epsilon-globin gene transcription: genetic confirmation of promoter competition during globin gene switching.}

K P Foley and J D Engel

Genes Dev. 1992, 6:

Access the most recent version at doi:10.1101/gad.6.5.730

References This article cites 91 articles, 41 of which can be accessed free at: http://genesdev.cshlp.org/content/6/5/730.full.html\#ref-list-1

License

Email Alerting Service

Receive free email alerts when new articles cite this article - sign up in the box at the top right corner of the article or click here.

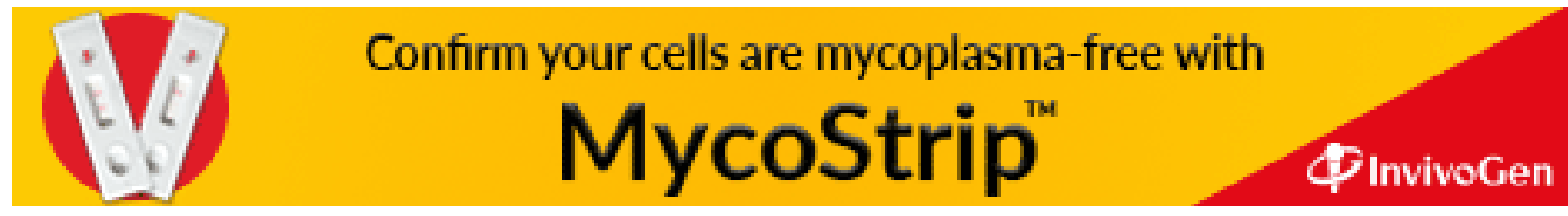

